Faculty Scholarship

1988

\title{
Rethinking Harmless Constitutional Error
}

\author{
A. Kimberley Dayton \\ Mitchell Hamline School of Law, kim.dayton@mitchellhamline.edu
}

\section{Publication Information}

88 Columbia La Review 791988

\section{Repository Citation}

Dayton, A. Kimberley, "Rethinking Harmless Constitutional Error" (1988). Faculty Scholarship. Paper 131. http://open.mitchellhamline.edu/facsch/131 


\title{
Rethinking Harmless Constitutional Error
}

\begin{abstract}
This article examines the increasing role of the Chapman Rule and its effect on the harmless error doctrine and outlines a coherent doctrine of constitutional error responsive to the purposes of the various constitutional protections afforded criminal defendants. Part I evaluates the Court's existing harmless error jurisprudence. Part II proposes a harmless error doctrine that, unlike the Court's approach, responds to constitutional values unrelated to truth determination. The last two parts of the Article address two problems precipitated by the use of outcome-oriented rules to define and remedy constitutional error. Part III discusses when such a rule should be used at trial to decide when constitutional error has occurred. Finally, Part IV develops a formulation of the Chapman rule that ensures that appellate courts will not rely upon their own evaluations of the weight and credibility of the evidence in deciding whether a constitutional error has affected the outcome.
\end{abstract}

\section{Keywords}

harmless error, Warren Court, Burger Court, Chapman v. California, Chapman Rule, constitutional error, criminal appeal

\section{Disciplines}

Constitutional Law | Criminal Law | Jurisprudence

\section{Comments}

This article is co-authored by Tom Stacy, Visiting Associate Professor of Law, University of Kansas. B.A. 1979; J.D. 1893, University of Michigan. 


\section{HEINONLINE}

Citation: 88 Colum. L. Rev. 791988

Content downloaded/printed from

HeinOnline (http://heinonline.org)

Thu Nov 18 17:36:22 2010

-- Your use of this HeinOnline PDF indicates your acceptance of HeinOnline's Terms and Conditions of the license agreement available at http://heinonline.org/HOL/License

-- The search text of this PDF is generated from uncorrected OCR text.

-- To obtain permission to use this article beyond the scope of your HeinOnline license, please use:

https://www.copyright.com/ccc/basicSearch.do?

\&operation $=$ go\&search Type $=0$

\&lastSearch $=$ simple\&all $=$ on\&titleOrStdNo $=0010-1958$ 


\title{
RETHINKING HARMLESS CONSTITUTIONAL ERROR
}

\author{
Tom Stacy* \\ E' Kim Dayton**
}

Since the early 1970s, some observers of the Supreme Court have predicted that the Burger Court would sweep aside many of the Warren Court's more controversial decisions involving civil liberties. ${ }^{1}$ In the area of constitutional criminal procedure, many believed that the Burger Court would overrule decisions such as Mapp v. Ohio ${ }^{2}$ and Miranda $v$. Arizona, ${ }^{3}$ which expanded rights that do not directly relate to a defendant's guilt or innocence. ${ }^{4}$ Writing in the early 1980s, however, a number of commentators argued that although the Burger Court's decisions regarding constitutional criminal procedure contained rhetoric exalting the truth-determining function of the criminal process over all others, the differences between the Burger and Warren Courts' substantive decisions had been greatly exaggerated. ${ }^{5}$

In distinguishing between rhetoric and reality, these commentators have overlooked the Burger and now Rehnquist Courts' increasingly widespread use of the doctrine of harmless constitutional error. After

* Visiting Associate Professor of Law, University of Kansas. B.A. 1979; J.D. 1983, University of Michigan.

** Associate Professor of Law, University of Kansas. B.A. 1980, University of Kansas; J.D. 1983, University of Michigan.

We would like to thank Professor Sid Shapiro for his insightful comments on an earlier draft of this Article. The research for this Article was supported by University of Kansas General Research allocation \#3832-XO-0038.

1. See, e.g., Dershowitz \& Ely, Harris v. New York: Some Anxious Observations on the Candor and Logic of the Emerging Nixon Majority, 80 Yale L.J. 1198, 1227 (1971); Stephens, The Burger Court: New Dimensions in Criminal Justice, 60 Geo. L. J. 249, 277 (1971).

2. 367 U.S. 643 (1961) (holding that the fourth amendment exclusionary rule applies to the states).

3. 384 U.S. 436 (1966).

4. E.g., L. Levy, Against the Law 68-75 (1974); Chase, The Burger Court, the Individual, and the Criminal Process: Directions and Misdirections, 52 N.Y.U. L. Rev. 518, 595 (1977).

5. See, e.g., 1srael, Criminal Procedure, The Burger Court, and the Legacy of the Warren Court, 75 Mich. L. Rev. 1319, 1324 (1977); Kamisar, The Warren Court (Was lt Really So Defense-Minded?), The Burger Court (1s It Really So Prosecution-Oriented?), and Police lnvestigatory Practices, in The Burger Court: The Counter-Revolution That Wasn't 62, 68 (V. Blasi ed. 1983); Saltzburg, Foreword: The Flow and Ebb of Constitutional Criminal Procedure in the Warren and Burger Courts, 69 Geo. L.J. 151, 158 (1980); Seidman, Factual Guilt and the Burger Court: An Examination of Continuity and Change in Criminal Procedure, 80 Colum. L. Rev. 436, 445-46 (1980). Professor Kamisar has recently retreated from his earlier appraisal of the Burger Court: Kamisar, The "Police Practice" Phases of the Criminal Process and the Three Phases of the Burger Court, in The Burger Years: Rights and Wrongs in the Supreme Court 1969-1986, 143, 145 (H. Schwartz ed. 1987) [hereinafter Kamisar, Police Practice Phases]. 
gradually applying the harmless error rule of Chapman $v$. Califormia $^{6}$ to more and more types of constitutional errors, the Supreme Court recently declared that the Chapman rule presumptively applies to virtually all types of federal constitutional errors. ${ }^{7}$ As a result, constitutional error generally does not necessitate automatic reversal of a criminal conviction: error is harmless and the conviction must be upheld when an appellate court concludes beyond a reasonable doubt that the error had no impact on the ultimate finding of guilt. ${ }^{8}$ With its harmless error doctrine, as well as with its holdings in other areas of criminal procedure, ${ }^{9}$ the Supreme Court clearly extends its preoccupation with factual guilt beyond mere rhetoric.

In justifying nearly ubiquitous use of a harmless error rule focusing on the outcome of the trial, the Supreme Court has appealed to the truth-determining function of the criminal trial, declaring that " the central purpose of a criminal trial is to decide the factual question of the defendant's guilt or innocence." "10 This reasoning, which lies at the very core of the Court's harmless error jurisprudence, denigrates

6. 386 U.S. 18 (1967). In this Article, we are concerned only with problems associated with the doctrine of harmless constitutional error in criminal prosecutions. For a discussion of some of the differences between constitutional and nonconstitutional harmless error rules, see United States v. Lane, 106 S. Ct. 725, 738 (1986) (Brennan, J., concurring in part and dissenting in part); Kotteakos v. United States, 328 U.S. 750 (1946); Goldberg, Harmless Error: Constitutional Sneak Thief, 71 J. Crim. L. \& Criminology 421, 422-23 (1980) (discussing history of nonconstitutional harmless error rules).

7. Rose v. Clark, 106 S. Ct. 3101, 3106-07 (1986) ("[I]f tbe defendant had counsel and was tried by an impartial adjudicator, there is a strong presumption that any other errors that may have occurred are subject to harmless error analysis."). For a list of the types of constitutional error that may be held harmless, see infra notes 27-32 and accompanying text.

8. Chapman, 386 U.S. at 24 ("beneficiary of a constitutional error [must] prove beyond a reasonable doubt that the error complained of did not contribute to the verdict obtained").

9. See, e.g., Colorado v. Connelly, 107 S. Ct. 515, 521-22 (1986) (constitutional rules that exclude reliable evidence from the criminal trial should be narrowly construed); Kuhlmann v. Wilson, 106 S. Ct. 2616, 2627 (1986) (plurality opinion) (habeas petitioner must make "colorable showing of factual innocence" to have court consider a successive habeas petition); United States v. Leon, 468 U.S. 897, 913, 922 (1984) (creating exception to exclusionary rule when police rely in good faith on warrant in obtaining evidence in violation of the fourth amendment); New York v. Quarles, 467 U.S. 649, 655 (1984) (creating "public safety" exception to Miranda); Stone v. Powell, 428 U.S. 465, 482 (1977) (fourth amendment violations generally are not cognizable in federal habeas corpus proceedings); see also Chase, supra note 4, at 519 (noting that the Court's decisions reflect a preoccupation with accurate results in individual cases); Cover \& Aleinikoff, Dialectical Federalism: Habeas Corpus and the Court, 86 Yale L.J. 1035, 1077 (1977) (discussing emphasis on factual gnilt-innocence in Court's habeas corpus decisions); Note, Guilt, Innocence, and Federalism in Habeas Corpus, 65 Cornell L. Rev. 1123, 1135 (1980) (noting Court's emerging view that habeas corpus should only protect constitutional claims directly concerning the process of gnilt-determination).

10. Rose, 106 S. Ct. at 3105-06 (quoting Delaware v. Van Arsdall, 106 S. Ct. 1431, 1436-37 (1986)). 
important constitutional protections accorded criminal suspects. By effectively treating all constitutional rights as designed to promote only factual accuracy, the Court undermines those rights that promote values other than the reliability of gnilty verdicts.

Scholars have for the most part ignored recent developments in this area. ${ }^{11}$ This inattention is most unfortunate. Although the resolution of an increasing proportion of direct appeals and habeas corpus proceedings now turns on an application of the Chapman rule, ${ }^{12}$ existing harmless error jurisprudence is seriously flawed in at least three respects. First, the Court's harmless error decisions rest on a premise that ignores the purposes of many fundamental constitutional protections enumerated in the Bill of Rights. Second, the Court has without explanation oscillated between use of two different standards of prejudice to define rights and identify constitutional error. When certain rights are involved, the Court has instructed trial courts not to find error unless the alleged infringement will likely affect the outcome of the trial. In contrast, with other rights, the Court has imposed a more relaxed standard that recognizes constitutional violations at trial regardless of whether they will affect the determination of gnilt. Third, the Court's opinions send conflicting signals concerning the scope of review that the Chapman harmless error rule entails. Existing formulations of the standard vary widely, ${ }^{13}$ and in applying these formulations,

11. The leading works are all more than 10 years old. R. Traynor, The Riddle of Harmless Error (1970); Field, Assessing the Harmlessness of Federal Constitutional Error-A Process in Need of a Rationale, $125 \mathrm{U}$. Pa. L. Rev. 15 (1976); Mause, Harmless Constitutional Error: The Implications of Chapman v. California, 53 Minn. L. Rev. 519 (1969); Saltzburg, The Harm of Harmless Error, 59 Va. L. Rev. 988 (1973). These works not only antedate several important developments, they also unquestioningly accept the basic premises of the Supreme Court's approach. See infra note 38. For student commentary, see Note, Harmful Use of Harmless Error in Criminal Cases, 64 Cornell L. Rev. 538 (1979) [hereinafter Cornell Note]; Note, Harmless Constitutional Error: A Reappraisal, 83 Harv. L. Rev. 814 (1970) [hereinafter Harvard Note]; Note, Harmless Constitutional Error, 20 Stan. L. Rev. 83 (1967) [hereinafter Stanford Note]; Note, Principles for Application of the Harmless Error Standard, 41 U. Chi. L. Rev. 616 (1974) [hereinafter Chicago Note].

12. Precise statistics as to the number of cases in the federal and state courts raising harmless constitutional error questions are unavailable. One commentator estimated in 1980 that "possibly as high as ten percent of all criminal appeals during the last thirteen years" involved an application of the Chapman harmless error rule. Goldberg, supra note 6, at 421 \& n.3; see also Cornell Note, supra note 11, at 544-48 (noting dramatic increase in number of cases in federal courts of appeals involving harmless error). In light of the Supreme Court's recent expansion of the doctrine to cover "most constitutional violations," United States v. Hasting, 461 U.S. 499, 509 (1983), as well as the substantial share of all habeas corpus proceedings that involve the Chapman rule, this $10 \%$ figure now seems unduly conservative.

13. Many courts and commentators have noted the confusion surrounding the meaning of harmless constitutional error. See, e.g., Holland v. Attorney Gen., 777 F.2d 150, 158-59 (3d Cir. 1985); Harryman v. Estelle, 616 F.2d 870, 885 (5th Cir. 1980) (T. Clark, J., concurring in part and dissenting in part), cert. denied, 449 U.S. 860 (1980); R.

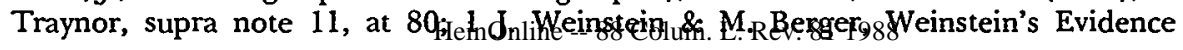


many courts have assumed virtually unreviewable discretion to evaluate the weight and credibility of the evidence. ${ }^{14}$ In effect, existing understandings of harmless error standards enable appellate courts to perform fact-finding functions that the sixth amendment entrusts to a jury.

This Article examines these criticisms and outlines a coherent doctrine of constitutional error responsive to the purposes of the various constitutional protections afforded criminal defendants. Part I evaluates the Court's existing harmless error jurisprudence. Part II proposes a harmless error doctrine that, unlike the Court's approach, responds to constitutional values unrelated to truth determination. The last two parts of the Article address two problems precipitated by the use of outcome-oriented rules to define and remedy constitutional error. Part III discusses when such a rule should be used at trial to decide when constitutional error has occurred. Finally, Part IV develops a formulation of the Chapman rule that ensures that appellate courts will not rely upon their own evaluations of the weight and credibility of the evidence in deciding whether a constitutional error has affected the outcome.

\section{Existing Harmless Error Doctrine}

\section{A. The Court}

The doctrine of harmless constitutional error is of relatively recent origin. Although statutes directing courts to find trial errors "harmless" unless they affect "substantial rights" have existed since the early twentieth century, ${ }^{15}$ until 1967 it was unclear whether constitutional er-

$\S 103[08$ ] (1986) [hereinafter Weinstein's Evidence]; Field, supra note 11, at 16; Saltzburg, supra note 11, at 988; Teitelbaum, Sutton-Barbere \& Johnson, Evaluating the Prejudicial Effect of Evidence: Can Judges ldentify the Impact of 1mproper Evidence on Juries?, 1983 Wis. L. Rev. 1147, 1177-81 [hereinafter Teitelbaum]; Note, Harmless Constitutional Error: An Analysis of Its Current Application, 33 Baylor L. Rev. 961, 961-64 (1981); Note, Confusion in the Court-Wisconsin's Harmless Error Rule in Criminal Appeals, 63 Marq. L. Rev. 643, 648 (1980); Note, Harmless Error: The Need for a Uniform Standard, 53 St. John's L. Rev. 541, 543-57 (1979) [hereinafter St. John's Note].

14. See United States v. Garza, 754 F.2d 1202, 1210 (5th Cir. 1985) (Goldberg, J., concurring) (" $[\mathrm{T}]$ he widespread use of the harmless error rule . . . can only lead to ad hoc decision-making, reflecting not impartial justice but the personal beliefs of the court regarding the defendant's guilt."); $c$ f. Goldberg, supra note 6 , at 436 ("Harmless constitutional error provides [both state and federal appellate courts] an opportunity to 'destroy or dilute constitutional guarantees." ") (quoting Harlan, J., dissenting in Chapman, 386 U.S. at 50 ).

15. For the history of modern harmless error statutes, see Chapman, 386 U.S. at 22; Mause, supra note 11, at 519-20; Stanford Note, supra note 11, at 83-84; Comment, Harmless Error: Abettor of Courtroom Misconduct, 74 J. Crim. L. \& Criminology 457, 459-60 (1983). The current federal harmless error statute, 28 U.S.C. $\$ 2111$ (1982), incorporates a harmless error statute enacted in 1919, Act of February 26, 1919, ch. 48, 40 Stat. 1181. In addition to the federal statute, the Federal Rules of Civil Procedure

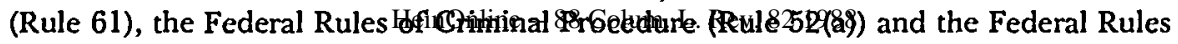


rors occurring in a criminal trial could ever be harmless. ${ }^{16}$ In Chapman v. California, ${ }^{17}$ however, the Supreme Court squarely rejected the notion that all constitutional errors require that a defendant's conviction be set aside. In Chapman, although noting that "some constitutional rights [are] so basic to a fair trial that their infraction can never be treated as harmless," 18 the Court nevertheless held that "there may be some constitutional errors which in the setting of a particular case are so unimportant and insignificant that they may, consistent with the federal constitution, be deemed harmless, not requiring the automatic reversal of the conviction." 19 Placing the burden of persuasion on the prosecution, the Court said that "before a federal constitutional error can be held harmless, the [reviewing] court must be able to declare a belief that it was harmless beyond a reasonable doubt."'20 It proceeded to apply this harmless error rule to the constitutional error before it, which involved the prosecutor's repeated comments on the defendant's failure to testify. ${ }^{21}$

Commentators writing in Chapman's immediate aftermath were uncertain whether most constitutional errors would be treated under a harmless error rule rather than a rule of automatic reversal. ${ }^{22}$ Appel-

of Evidence (Rule 103(a)) all contain harmless error provisions. All 50 states have harmless error statutes or rules. Chapman, 386 U.S. at 22.

16. Before Chapman, those federal courts to consider the question had generally assumed that constitutional error was always harmful. See, e.g., Kotteakos v. United States, 328 U.S. 750, 764-65 (1946); Starr v. United States, 264 F.2d 377, 381 (D.C. Cir. 1958), cert. denied, 359 U.S. 936 (1959); Fina v. United States, 46 F.2d 643, 644 (10th Cir. 1931). But see Motes v. United States, 178 U.S. 458, 475-76 (1900) (violation of sixth amendment right of confrontation harmless when defendant had confessed under oath). In Fahy v. Connecticut, 375 U.S. 85 (1963), the Supreme Court intimated, but did not actually hold, that constitutional error could in some circumstances be harmless. See generally Gibbs, Prejudicial Error: Admissions and Exclusions of Evidence in the Federal Courts, 3 Vill. L. Rev. 48, 67 (1957) (reversal follows constitutional error regardless of error's consequences); Mause, supra note 11, at 520-23 (discussing pre-1967 uncertainty as to whether constitutional error could be harmless).

17. 386 U.S. 18 (1967).

18. Id. at 23.

19. 1d. at 22 .

20. Id. at 24 .

21. Id. at 24-26. In Griffin v. California, 380 U.S. 609 (1965), the Court held that prosecutorial or judicial comment on the defendant's failure to testify unduly burdens the exercise of the fifth amendment privilege against self-incrimination and thus amounts to constitutional error.

22. See, e.g., Mause, supra note 11, at 557 (suggesting that Chapman could be read as creating an exception to "a general rule of automatic reversal"); Stanford Note, supra note II, at 98. Other commentators speculated that as a practical matter, Chapman would have little impact on criminal appeals involving constitutional error because "the possibility that a particular error will be found 'harmless beyond a reasonable doubt' seems slight." The Supreme Court, 1966 Term, 81 Harv. L. Rev. 110, 207 (1967); cf. Rose v. Clark, 106 S. Ct. 3101, 3111 (1986) (Stevens, J., concurring in the judgment) ("Rather than creating a broad, new presumption in favor of harmless error analysis ... Chapman merely rejected the notionothate sughcanalysis Reas salways impermissible and 
late courts likewise exhibited uncertainty regarding the specific rights to which Chapman applies. ${ }^{23}$ After expanding the category of constitutional rights subject to the Chapman rule for more than a decade, the Supreme Court finally clarified its approach, stating that "it is the duty of a reviewing court to consider the trial record as a whole and to ignore errors that are harmless, including most constitutional violations." 24 Recently, in Rose v. Clark, ${ }^{25}$ the Court went further, declaring that the Chapman rule is presumptively appropriate for virtually every kind of constitutional error. According to the Rose Court: "while there are some errors to which Chapman does not apply, they are the exception and not the rule.... [I]f the defendant had counsel and was tried by an impartial adjudicator, there is a strong presumption that any other errors that may have occurred are subject to harmless error analysis." 26

As these statements suggest, the Chapman outcome-oriented harmless error rule now applies to a broad array of constitutional errors. Errors the Court has held may be deemed harmless include errors involving the fourth amendment, ${ }^{27}$ the right to cross-examine adverse witnesses, ${ }^{28}$ the right to adduce exculpatory evidence at trial ${ }^{29}$ the right of a defendant to be present at all critical stages of the proceeding ${ }^{30}$ and the right to have counsel at a pretrial lineup. ${ }^{31}$ Lower courts have

articulated a rigorous standard for determining whether a presumptively prejudicial error could, in fact, be deemed harmless.").

23. For example, until the Supreme Court's decision in Rose v. Clark, 106 S. Ct. 3101 (1986), lower courts had divided over whether an improper burden-shifting instruction could ever be considered harmless. Compare Tucker v. Kemp, 762 F.2d 1496, 1501-03 (11th Cir. 1985) (en banc) (Chapman applies), cert. denied, 106 S. Ct. 3340 (1986) with In re Hamilton, 721 F.2d 1189, 1190-91 (9th Cir. 1983) (Chapman inapplicable if intent is at issue); see also infra note 152 ..

24. United States v. Hasting, 461 U.S. 499, 509 (1983) (emphasis added).

25. 106 S. Ct. 3101 (1986).

26. Id. at 3106-07 (citations omitted).

27. Chambers v. Maroney, 399 U.S. 42, 53 (1970); Bumper v. North Carolina, 391 U.S. 543, 550 (1968).

28. Lee v. Illinois, 106 S. Ct. 2056, 2065-66 (1986); Delaware v. Van Arsdall, 106 S. Ct. 1431,1438 (1986).

29. Crane v. Kentucky, 106 S. Ct. 2142, 2147 (1986). (1970).

30. Rushen v. Spain, 464 U.S. 114, 121 (1983); Coleman v. Alabama, 399 U.S. 1, 11

31. Moore v. Illinois, 434 U.S. 220, 232 (1977). Other constitutional errors that the Court has expressly or impliedly held subject to the Chapman rule include the due process right against a burden-shifting jury instruction, Rose v. Clark, 106 S. Ct. 3101, 3107 (1986); the due process right against improper prosecutorial argument, Darden v. Wainwright, $106 \mathrm{~S}$. Ct. 2464, $2472-73$ (1986); the due process right against unduly suggestive pretrial identification procedures, Manson v. Brathwaite, 432 U.S. 98, 113-14 (1977); violations of the right of confrontation upon the admission of inculpatory out-ofcourt statements made by nontestifying codefendants (the doctrine of Bruton v. United States, 391 U.S. 123 (1968)), Brown v. United States, 411 U.S. 223, 231-32 (1973); the sixth amendment right not to be interrogated by goverument agents once the right to

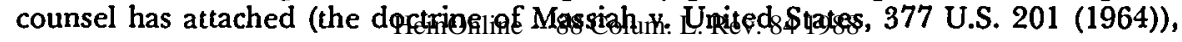


expanded this list, adding, for instance, Miranda violations. ${ }^{32}$ In addition to using an outcome-oriented test as a harmless error rule to determine the availability of a remedy for constitutional error, the Court has in some contexts used such a standard as a prejudice test to define whether constitutional error has occurred at trial. A defendant, for instance, has a right to discover exculpatory evidence in the government's possession only if there is a "reasonable probability" that the evidence will affect the trial's outcome. ${ }^{33}$ The cumulative effect of all of these developments is that appellate courts now regularly uphold convictions because an asserted error had no impact on the result of the proceeding. ${ }^{34}$

It is important to understand the reasoning that the Court has used to extend the reach of the Chapman harmless error rule and the "reasonable probability of a different result" prejudice test. Language in the Court's harmless error decisions occasionally suggests that a concern for judicial efficiency justifies the doctrine of harmless error. ${ }^{35}$ Yet the Court has implicitly acknowledged that, at least on direct appeal, the interests of judicial efficiency and finality do not permit reviewing courts idly to countenance a constitutional violation that has thwarted a particular right's core purpose.

Milton v. Wainwright, 407 U.S. 371, 378 (1972); the sixth amendment right to confrontation, Harrington v. California, 395 U.S. 250, 253-54 (1969); cf. Hopper v. Evans, 456 U.S. 605, 613-14 (1982) (citing Chapman and finding no prejudice from trial court's failure to instruct on lesser-included offenses).

32. Federal appellate courts have uniformly held that Miranda violations, see Miranda v. Arizona, 384 U.S. 436 (1966), may constitute harmless error. See, e.g., Gorham v. Franzen, 760 F.2d 786, 795-96 (7th Cir.), cert. denied, 474 U.S. 922 (1985); United States v. Hall, 739 F.2d 96, 100 (2d Cir. 1984); United States v. Packer, 730 F.2d 1151, 1157 (8th Cir. 1984); Harryman v. Estelle, 616 F.2d 870, 875-77 (5th Cir.) (en banc), cert. denied, 449 U.S. 860 (1980). The Supreme Court, however, has never held that Miranda violations are subject to harmless error analysis. See Berkemer v. McCarty, 468 U.S. 420,444 n. 40 (1984) (leaving issue open).

Other constitutional errors that lower courts have subjected to harmless error analysis include the failure to instruct the jury on an essential element of the offense, Redding v. Benson, 739 F.2d 1360 (8th Cir. 1984), cert. denied, 469 U.S. 1222 (1985); and governmental intimidation of a potential defense witness, Peeler v. Wyrick, 734 F.2d 378 (8th Cir.), cert. denied, 469 U.S. 1020 (1984).

33. United States v. Bagley, 473 U.S. 667, 682 (1985) (Blackmun, J.). In Bagley, although only Justice O'Connor joined in Justice Blackmun's "reasonable probability" language, three other Justices indicated that they agreed with that standard. See Bagley, 473 U.S. at 685 (White, J., joined by Burger, C.J., and Rehnquist, J., concurring in part and concurring in the judgment). See generally infra notes 155-219 and accompanying text.

34. See United States v. Lane, 106 S. Ct. 725, 744-45 (1986) (Stevens, J., dissenting) (noting increasing use of harmless error doctrine); Cornell Note, supra note 11, at 539.

35. "The goal [of harmless error analysis], as Chief Justice Traynor has noted, is to 'conserve judicial resources by enabling appellate courts to cleanse the judicial process of prejudicial error without becoming mired in harmless error.' " United States v. Hasting, 461 U.S. 499, 509 (1983) (EHPting R. Trayner supra ngte 11, at 81). 
The Court's justification for its expanded use of the Chapman rule and an outcome-oriented prejudice test ostensibly recognizes the hegemony of constitutional purpose over judicial efficiency. The Court apparently views the ultimate end of the criminal process and constitutional criminal procedure as securing the accused a fair trial. Yet the Court has expressed a reductionistic notion of what a "fair trial" means, defining it merely as a trial designed to produce a reliable outcome. ${ }^{36}$ It follows from this definition that the fairness of the trial is not impaired by a constitutional error that has had no effect on the finding of guilt. ${ }^{37}$ The last step implicit in the Court's reasoning is that when constitutional error does not impair the fairness of the trial, concerns for judicial efficiency and finality justify upholding the conviction. The interesting feature of this reasoning, which commentators have yet to question, ${ }^{38}$ is that it presumes the reliability of the result and judicial

36. See, e.g., Strickland v. Washington, 466 U.S. 668, 686-87 (1984) ("In giving meaning to [the constitutional requirement of effective assistance of counsel], we must take its purpose-to ensure a fair trial-as the guide .... . This requires showing that counsel's errors were so serious as to deprive the defendant of a fair trial, a trial whose result is reliable.") (emphasis added); see also Bagley, 473 U.S. at 678 (Suppression by prosecutor of potentially exculpatory impeachment evidence "amounts to a constitutional violation only if it deprives the defendant of a fair trial. Consistent with 'our overriding concern with the justice of the finding of guilt,' a constitutional error occurs, and the conviction must be reversed, only if the evidence is material in the sense that its suppression undermines confidence in the outcome of the trial.") (quoting United States v. Agurs, 427 U.S. 97, 112 (1976)); Chase, supra note 4, at 520-24 (discussing Burger Court's conception of a "fair trial" as one that ensures a factually correct result).

37. See Delaware v. Van Arsdall, 106 S. Ct. 1431 (1986):

The harmless-error doctrine recognizes the principle that the central purpose of a criminal trial is to decide the factual question of the defendant's guilt or innocence, and promotes public respect for the criminal process by focusing on the underlying fairness of the trial rather than on the virtually inevitable presence of immaterial error.

Id. at 1436-37 (citation omitted).

38. The commentators have essentially accepted the basic parameters of the Court's harmless error jurisprudence. Although some scholars have noted that the criminal justice system protects values other than reliability, see, e.g,. W. LaFave \& J. Israel, Criminal Procedure 28-31 (1985), we have found no commentary criticizing the Court for overemphasizing the truth-determination function of constitutional criminal procedure in extending the reach of the Chapman rule. Consistent with the Court's emphasis on the reliability of the verdict, scholars have generally concentrated on whether and how courts can accurately measure the impact of particular types of errors on the result.

Some commentators address which of the many possible formulations of an outcome-oriented harmless error rule best ensures reliability. See, e.g., R. Traynor, supra note 11, at 17-25; Field, supra note 11, at 16; Saltzburg, supra note 11, at 1030-32; Harvard Note, supra note 11, at 817-29. Some commentary also focuses on the choice between the Chapman rule and a rule of automatic reversal, assuming, as the Court does, that the choice should turn on considerations relating to the reliability of the result. See R. Traynor, supra note 11, at 58-65; Field, supra note 11, at 19-21; Saltzburg, supra note 11, at 1026-27; Chicago Note, supra note 11, at 627; Cornell Note, supra note 11,

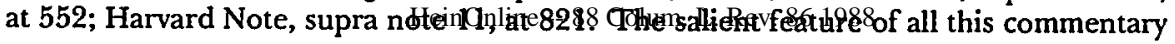


economy to be the only values relevant to deciding the appropriate remedy for constitutional error. ${ }^{39}$

The Supreme Court's preoccupation with reliability not only is evident in the sweeping statements the Court has made about the rationale for harmless error review; it also underlies the Court's explanation of the distinction between the very broad range of constitutional errors subject to the Chapman rule and the much narrower category of errors requiring automatic reversal. All members of the Court appear to agree that violations of the rights to counsel, to an impartial tribunal and against coerced confessions can never be considered harmless. ${ }^{40}$ But what common features distinguish these rights from, for example, the right to confront adverse witnesses or the right to compulsory process, both of which are subject to the Chapman rule? Those rights whose violation require automatic reversal, the Court has said, are so basic or fundamental to a "fair trial" that in their absence "a criminal trial cannot reliably serve its function as a vehicle for determination of guilt or innocence . . . and no criminal punishment may be regarded as fundamentally fair."41 According to the Court, the distinctive characteristic

is its acceptance of the premise that the harmless error doctrine should revolve around the truth-determination function of a trial.

39. Some of the Court's opinions suggest that it may not be completely insensitive to truth-neutral and truth-impairing values in shaping the doctrine of harmless constitutional error. In Rose v. Clark, 106 S. Ct. 3101, 3107 (I986), for instance, the Court noted that the purpose of the constitutional right at issue there-the right to have the prosecution prove each element of the crime beyond a reasonable doubt-is truth-furthering and said that tbis purpose supported its decision to apply the Chapman rule. See also McKaskle v. Wiggins, 465 U.S. $168,177 \mathrm{n} .8$ (1984) ("Since the right of self-representation is a right that when exercised usually increases the likelihood of a trial outcome unfavorable to the defendant, its denial is not amenable to 'harmless error' analysis.") (dictum). The Court might be understood as suggesting that the Chapman rule may be inappropriate for non-truth-furthering rights.

Yet the Court has never articulated a theory that expressly ties the choice between the Chapman rule and a rule of automatic reversal to the nature of the purpose of the right in question. In Rose, for instance, the truth-furthering purpose of the right before it did not provide the primary rationale for its decision to apply the Chapman rule. Rose, $106 \mathrm{~S}$. Ct. at 3107. Furthermore, the Court has applied the Chapman rule to violations of fourth and fifth amendment rights, see supra notes $27 \& 21$, respectively, without making any attempt to reconcile harmless error review with those rights' truth-impairing purposes. In fact, the considerations the Court has articulated as governing the choice between Chapman and a rule of automatic reversal relate only to the reliability of the trial result. See infra notes $40-43$ and accompanying text.

Among the Justices, only Justice Stevens has decried the Court's harmless error jurisprudence for failing to accord proper respect to "other values besides the reliability of the guilt or innocence determination." Rose, $106 \mathrm{~S}$. Ct. at 3111-12 (Stevens, J., concurring in the judgment). Justice Stevens, however, has not proposed a coherent theory of harmless error that would take account of these "other values." Id. at 3111 (Stevens, J., concurring in the judgment).

40. See, e.g., Rose, $106 \mathrm{~S}$. Ct. at 3106 (dictum); id. at 3111 (Stevens, J., concurring in the judgment); id. at 3114 (Blackmun, J., dissenting); Van Arsdall, 106 S. Ct. at 1437.

41. Rose, $106 \mathrm{~S}$. Ct. at 3106 (kitatiolinomitued) (remplRasis 8 add8d). 
of these violations is that it is either extremely difficult to know whether they might have affected the outcome, ${ }^{42}$ or the likelihood that they have influenced the outcome is so strong that it is not worth expending the judicial resources necessary to evaluate the effect of the error in particular cases. ${ }^{43}$ Under the Court's theory, then, the choice between the Chapman rule and a rule of automatic reversal is governed by considerations relating to the reliability of the result.

\section{B. Criticisms of Prevailing Doctrine}

The most basic flaw in the Court's approach is that it ignores the central axiom that in fashioning remedial rules to correct violations of constitutional rights, courts must be sensitive to the fundamental purposes of those rights. ${ }^{44}$ The Court's theory of harmless error-the sweeping statements it has made about the doctrine's rationale and the

42. Id. at 3107 n.7; Vasquez v. Hillery, 106 S. Ct. 617, 623-24 (1986); Holloway v. Arkansas, 435 U.S. 475, 490-91 (1978).

43. United States v. Cronic, 466 U.S. 648, 659-60 (1984). One might argue that errors involving rights that pervade the entire trial process must be reversed automatically because they have a special symbolic importance. This argument would assert that wholly apart from their contribution to a reliable result, rights such as the right to counsel and the right to an impartial tribunal are essential to society's perception of fairness. Because of their lack of clarity, certain of the Justices' opinions can be read as embracing this view. See Gray v. Mississippi, I07 S. Ct. 2045, 2056 (1987) ("because the impartiality of the adjudicator goes to the very integrity of the legal system, the Chapman harmlesserror analysis cannot apply") (Blackmun, J.) (plurality opinion) (emphasis added); Vasquez, $106 \mathrm{~S}$. Ct. at 624 (racial "discrimination in the grand jury undermines the structural integrity of the criminal tribunal itself") (Marshall, J.) (plurality opinion) (emphasis added).

The supposed symbolic importance of rights that pervade the entire trial process is unpersuasive as a rationale for choosing between the Chapman rule and a rule of automatic reversal. Because this reasoning focuses on the pervasive function rather than the fundamental values of the right at stake, it seeks to create a symbolism that is disembodied from those values. Further, it posits that courts should be concerned with an appearance of impropriety even though that appearance has no basis whatever in reality. If the evidence of guilt is so overwhelming that any rational jury would be compelled to convict the defendant, then the appearance of unfairness created by the denial of a truth-furthering right is simply illusory. See infra text accompanying note 149.

44. To prevent substantive constitutional guarantees from becoming merely "a form of words," Mapp v. Ohio, 367 U.S. 643, 655 (196I), courts are constitutionally required to fashion remedies necessary to effectuate those guarantees. See Bivens v. Six Unknown Fed. Narcotics Agents, 403 U.S. 388, 392 (1971); Bell v. Hood, 327 U.S. 678, 684 (1946) ("[W] from the beginning that courts will be alert to adjust their remedies so as to grant the necessary relief."); Marbury v. Madison, 5 U.S. (I Cranch) 137, 163 (1803) ("The government of the United States has been emphatically termed a government of laws, and not of men. It will certainly cease to deserve this high appellation, if the law will furnish no remedy for the violation of a vested legal right."); C. Black, The Unfinished Business of the Warren Court, 46 Wash. L. Rev. 3, 28 (1970) ("[L]aw . . . is a practical subject, and the first principle of law is that its commands, and above all its promises, are to be translated into practice . . . ."); Schrock \& Welsh, Reconsidering the Constitutional Common Law, 91 Harv. L. RevinQnilitf,-1885eB/7n(1978); Stefman, Backing Off Bivens 
reasons it has advanced in choosing between the Chapman rule and a rule of automatic reversal in particular cases-is predicated on a conception of a fair trial that incorporates only the value of factual accuracy. Yet even if the Court is correct in asserting that the "central purpose" 45 of most of a defendant's constitutional rights "is to ensure that [criminal] trials lead to fair and correct judgments," 46 it is certainly incorrect to conclude that this is the purpose of all such rights.

There can be no question that some constitutional rights, by design, oblige police, prosecutors and courts to follow certain procedures not because those procedures enhance the accuracy of the ultimate finding of guilt or innocence, but because they foster other goals or values. Some of these rights are even truth impairing; that is, they deliberately subordinate the concern for accurate truth determination to other values. Fourth amendment rights, which protect privacy values at the expense of the search for the truth, are examples of such truthimpairing rights. ${ }^{47}$ The fifth amendment privilege against self-incrimination is another example; it seeks to protect interests, such as privacy and dignity, that are unrelated to truth determination. ${ }^{48}$ Other rights can be characterized as truth neutral because they have neither a positive nor a negative impact on the reliability of the result in a criminal proceeding. The various equal protection rights accorded to criminal defendants, such as the right to a grand jury selected in a race-neutral fashion, exemplify rights in this category. At least one of the purposes of a defendant's equal protection rights is to ensure that members of "suspect classes" participate in goverumental processes on an equal footing with others. This purpose, of course, is not directly related to a concern for factual accuracy. ${ }^{49}$ Finally, some rights, including many of the classic truth-furthering rights upon which the Court has relied in extending the reach of the Chapman rule, have mixed purposes: they seek not only to foster the reliability of the fact-finding process, but also to promote other truth-neutral values such as participation or fair play. ${ }^{50}$

If one accepts the proposition that some constitutional rights have purposes other than, or in addition to, promoting the reliability of gnilty verdicts, the flaw in the Court's approach to harmless error analysis becomes obvious. In fashioning remedial rules to correct

and the Ramifications of this Retreat for the Vindication of First Amendment Rights, 83 Mich. L. Rev. 269, 278-81 (1984).

45. Delaware v. Van Arsdall, 106 S. Ct. 1431, 1436 (1986).

46. Rose, $106 \mathrm{~S}$. Ct. at 3107.

47. See Schneckloth v. Bustamonte, 412 U.S. 218, 242 (1973); see infra notes 99-101 and accompanying text.

48. See Allen v. lllinois, 106 S. Ct. 2988, 2995 (1986); see infra notes 91-93 and accompanying text.

49. See Rose, $106 \mathrm{~S}$. Ct. at 3111 (Stevens, J., concurring in the judgment); see also infra notes 81-82 and accompanying text.

50. See, e.g., infra notes 120-36 and accompanying text 1988 
constitutional error, courts must begin witb an assessment of the fundamental purposes of the right implicated by the error; only then can they select a remedy that will adequately protect that right's basic purposes. Imagine, for instance, a case in which the prosecutor has used his peremptory challenges to deny a clearly guilty defendant his equal protection right to have the petit jury selected in a race-neutral fashion. A court should be concerned with vindicating the right's participatory purpose rather than the defendant's guilt. The Court's theory of harmless error glosses over this essential step in constitutional analysis, substituting its reliability conception of a fair trial for a systematic consideration of the purposes of particular rights.

One might try to justify the Court's harmless error jurisprudence by ascribing more weight to the value in ensuring a reliable result than to the values underlying truth-neutral and truth-impairing rights. According to this justification, the stronger interest in factual accuracy triumphs over the interests of finality and judicial efficiency while the weaker truth-neutral and truth-impairing interests do not. Retrial, the argument runs, is accordingly required when a constitutional violation may have affected the outcome but not when such a violation, though frustrating the core purpose of a truth-neutral or trutb-impairing right, has not affected the outcome.

This reasoning finds no support in the Constitution. ${ }^{51}$ The Constitution does not create a hierarchy of rights or values. There is no historical or structural reason to suppose that the framers intended rights having truth-furthering purposes to carry more weight than rights having other purposes. Admittedly, it may seem wasteful to vacate a defendant's conviction and require retrial when we are quite convinced that he will only be convicted again. But the Constitution is not merely concerned with the end result of criminal trials; it is also concerned with process. The Chapman rule ensures that retrial occurs when necessary to effectuate the purpose of a truth-furthering right that has been violated. Because truth-impairing and truth-neutral rights are no less important in the constitutional scheme, retrial should also be required

51. Several Justices, led by Justice Powell, have embraced a distinction between truth-furthering and non-truth-furthering rights in supporting limitations on the scope of federal habeas corpus review. See, e.g., Kuhlmann v. Wilson, 106 S. Ct. 2616, 2627 (1986) (opinion of Powell, Rehnquist, O’Connor, JJ., \& Burger, C.J.); Stone v. Powell, 428 U.S. 465, 491-92 n.31 (1976); Schneckloth, 412 U.S. at 262, 266 (Powell, J., concurring). This distinction can perhaps be justified as a matter of statutory construction of the habeas corpus statutes in view of the greater sway that the interests in finality and federalism hold in federal habeas proceedings. But see Peller, ln Defense of Federal Habeas Corpus Relitigation, 16 Harv. C.R.-C.L. L. Rev. 579, 661-69 (1982); Yackle, Explaining Habeas Corpus, 60 N.Y.U. L. Rev. 991, 1019-40 (1985). But the notion that truth-furthering rights deserve greater weight than non-truth-furthering rights on direct appeal cannot be defended as a matter of constitutional interpretation. Not surprisingly, no Justice has suggested that it can. 
when necessary to vindicate the various purposes of such rights. ${ }^{52}$

\section{Choosing Among Remedies for Constitutional Error}

Courts need a principled method for choosing the remedial rule to apply when constitutional error has occurred. Under existing doctrine, courts choose between the Chapman rule and a rule requiring automatic reversal of conviction based on considerations relating only to factual accuracy. This Part proposes a three-step method for choosing remedial rules for constitutional error that begins by asking the purpose of the particular right in question. This method, unlike current doctrine, protects the values underlying all of a criminal defendant's constitutional rights, not simply those rights designed to enhance the accuracy of the truth-determination process.

\section{A. A Proposed Framework}

The method proposed here, which focuses explicitly on the purposes of particular rights, involves three interrelated inquiries. The first is whether the violation has impaired the purposes of the constitutional right in question. Constitutional error does not necessarily undermine a right's fundamental goals. If in a particular case it has not, then the conviction should be upheld unless deterrence requires otherwise. ${ }^{53}$

The second inquiry, which arises only after concluding that the violation has impaired the right's purposes, considers whether redoing the adjudicative process can effectively cure the harm caused by the violation. The loss of privacy that results from a fourth amendment violation, for instance, cannot be cured by redoing the adjudicative or even the investigative process leading to the conviction. In this situation,

52. One could perhaps defend the Court's harmless error jurisprudence in yet another way. This approach would concede that the values underlying truth-furthering and non-truth-furthering rights are entitled to equal weight, but point out that only nontruth-furthering rights conflict sharply with the societal interest in convicting the guilty. This sharp conflict, one could argue, should cause courts to construe the scope of nontruth-furthering rights more narrowly. Yet this line of reasoning, even if accepted, cannot justify holding a violation of the central purpose of a non-truth-furthering right harmless simply because the trial outcome was unassailably correct. If accepted, the argument only supports taking a more parsimonious approach to construing the scope of non-truth-furthering rights. Once the scope of such a right has been determined giving appropriate weight to the interest in convicting the guilty, it would make little sense to hold a violation of it harmless even though the right's core truth-neutral or truth-impairing purpose has been frustrated and retrial would vindicate that purpose. To do so would sap the right of meaning and would anomalously give double effect to the interest in convicting the guilty.

53. Violations of the prosecution's Brady obligation, Brady v. Maryland, 373 U.S. 83 (1963), to disclose exculpatory evidence to the defense, for example, may require that a defendant's conviction be vacated even though the violation has not impaired the truthfurthering aim of the obligation. See infra notes 103-08, 182-84 and accompanying text. 
reversal is not required to vindicate the right's purposes in the case before the court; the remedial rule can only be concerned with deterring future violations. ${ }^{54}$

The third inquiry considers the role of deterrence. Even if reversal is not necessary to effectuate the purposes of the right violated in the particular case before the court, reversal may be necessary to deter future violations. Indeed, a sanction more severe than reversal may be required to compensate for the probability that any given error involving this particular right will go undetected.

1. The Effect of the Violation on the Right's Purpose(s). - Considerations of deterrence aside, a conviction should be upheld when constitutional error has not frustrated a right's basic purposes: ${ }^{55}$ the right's underlying values do not support or require reversal, and systemic interests in finality and judicial economy tip the balance in favor of affirmance. The apparent simplicity of this analysis masks some important complications.

Consider first rights whose only purposes are truth furthering. These rights operate to protect innocent persons from wrongful conviction; they relate to the premise that "it is far worse to convict an innocent man than to let a guilty man go free," 56 and foster confidence that criminal convictions will fall only on those who are actually guilty. ${ }^{57}$ The purpose of a truth-furthering right is not frustrated in a particular case if, despite the error, the record as a whole conclusively demonstrates the defendant's guilt or at least demonstrates that the violation could have had no effect on the jury's decision to convict. Truth-furthering rights would thus seem to be ideally suited for Chapman's harmless error rule, which ensures reversal of the conviction when reliability may have been impaired, but requires affirmance when the court is substantially certain that the constitutional error did not undermine reliability. ${ }^{58}$

This conclusion assumes that the reviewing court can reliably ascertain whether constitutional error may have affected the outcome. The assumption seems valid with respect to most truth-furthering rights. ${ }^{59}$ Suppose, for instance, that a trial court has abridged a defend-

54. See Brown v. 1llinois, 422 U.S. 590, 599-600 (1975).

55. Some constitutional rights are defined more broadly than is strictly required to vindicate their purposes in a particular case. A violation of such a right does not inevitably infringe upon the right's purposes. For a discussion of the reasons for defining a truth-furthering right more broadly than its purpose strictly requires, see infra notes 155-84 and accompanying text. Non-truth-furthering rights may also be defined more broadly than is required to protect their purposes in any given case.

56. In re Winship, 397 U.S. 358, 372 (1970) (Harlan, J., concurring).

57. Id. at 364 .

58. Even in the case of errors involving truth-furthering rights, the interest in deterring police or prosecutorial misconduct may warrant reversing the conviction of a clearly guilty defendant. See infra notes $68-74$ and accompanying text.

59. To be sure, applicatipn thef the Chapmgn rule keaves r98m for disagreement and 
ant's sixth amendment right to cross-examine a government witness for bias. ${ }^{60}$ As in most circumstances involving the denial of a truth-furthering right, the record in this situation will contain all of the information a reviewing court needs to apply Chapman's harmless error rule: the substance of the excluded evidence, the other evidence elicited by the defense and the evidence of guilt presented by the prosecution. Because the parties can be expected to bring the relevant aspects of the record to its attention, a reviewing court should not have undue difficulty determining whether the error may have affected the decision of a reasonable jury.

In contrast, courts sometimes lack the information they need to apply the Chapman rule. When a defendant has been denied counsel altogether, for instance, the evidence of guilt may appear compelling on the basis of the existing record. But that record does not contain the evidence and legal argument a defense attorney might have generated. A reviewing court could obtain the missing information by imposing on a defendant the burden of producing evidence showing how counsel would have made a difference. But this anomalous burden of production would require that an uncounseled defendant articulate how counsel could have helped him when his ignorance of what counsel could have done is the reason for requiring counsel to begin with. ${ }^{61}$ Thus, in this situation, as in other situations where the record does not enable a court to apply the Chapman rule reliably, ${ }^{62}$ the conviction must be reversed automatically. Lacking critical information, courts may tend to underestimate the effects of constitutional error. As the Supreme Court has sometimes acknowledged, ${ }^{63}$ the only safe option is

error. It requires the court to make a judgment concerning whether excluded impeachment evidence, for example, might make a difference to a reasonable jury. Yet our system tolerates error and disagreement arising from applying the admittedly imprecise "reasonable jury" standard. No one contends, for instance, that this imprecision warrants abolition of summary judgment and directed verdict procedures, where courts also apply a "reasonable jury" standard. See infra notes 202-04 and accompanying text.

60. See, e.g., Delaware v. Van Arsdall, I06 S. Ct. 1431 (I986).

6I. See Gideon v. Wainwright, 372 U.S. 335, 345 (I963); Powell v. Alabama, 287 U.S. 45,69 (1932).

62. See, e.g., infra notes I37-42 (right to a public trial). Unlike cases in which a defendant has been denied counsel altogether, a reviewing court should be able to apply the Chapman rule reliably when the trial has erroneously excluded evidence proffered by the defense. In this latter situation, a defendant is, through his counsel, aware of the nature of the excluded evidence; indeed, he is typically required to make at least a proffer of its import to preserve the issue for appeal.

63. The Court has from time to time used language suggesting that automatic reversal is justified when it is exceedingly difficult to determine whether an error resulted in an unreliable verdict, see, e.g., Holloway v. Arkansas, 435 U.S. 475, 490-91 (1978), but it has not expressly justified in these terms its decisions applying a rule of automatic reversal. Nor has it cast the question of whether automatic reversal is necessary in terms of whether a right's purposes require this remedy for a violation. This has led to a great deal of confusion in cases involving non-truth-furthering rights such as the fifth amendment. See infra notes 84-98 and Afergmpanzingotext.L. Rev. 931988 
for courts to assume as a matter of course that error has undercut the right's truth-furthering purpose.

Although in most situations the Chapman rule may be relied upon to identify when constitutional error has undermined the purpose of a truth-furthering right, it furnishes no guide in determining whether the purpose of a truth-neutral or a truth-impairing right has been thwarted. Courts must focus on the particular truth-neutral or truth-impairing purpose in question, not the impact of the error on the outcome of the proceeding. If constitutional error has not frustrated that purpose, the error is harmless and the court should uphold the conviction unless reversal is necessary to deter future violations.

2. The Value of Redoing the Process. - If a court concludes that a constitutional error has impaired the purpose of the right in question, it must then ask whether redoing the adjudicative process can cure the damage. If it can, the conviction must be reversed and the process redone to effectuate the purpose of the right in that case, thereby making the defendant whole. If, on the other hand, redoing the process cannot undo the harm caused by constitutional error, reversal may be pointless. The interests in judicial economy and finality require that the conviction be upheld unless reversal or some more severe sanction can be justified on grounds of deterrence.

In determining whether redoing some aspect of the adjudicative process can cure the damage the violation has caused, a court must again focus on the purpose of the right in question. Obviously, redoing the adjudicative process can undo the harm that stems from error involving a truth-furthering right, for the harm caused by such errors occurs during that process and is related to its end result. When, for example, the court has erroneously excluded exculpatory evidence, the remedy of a new trial at which the evidence is admitted can remove any possibility of an unreliable result created by the error.

But in certain instances involving non-truth-furthering rights, redoing the trial or some other aspect of the adjudicative process cannot rectify the constitutional errors. For example, the fourth amendment carves out a zone of personal privacy into which the goverument may not unreasonably intrude. Once the government has invaded this private sphere and exposed it to public view by introducing illegally seized evidence at trial, a new trial cannot restore the loss of privacy. The same conclusion applies to violations of the fifth amendment privilege against self-incrimination if one understands the privilege as shielding a sphere of mental privacy from governmental intrusion. ${ }^{64}$

Of course, errors involving other non-truth-furthering rights can be cured by redoing the adjudicative process. For example, the right to

64. Double jeopardy violations furnish another example. One of the purposes of the double jeopardy ban against retrial is to "protect an individual from suffering the embarrassment, anxiety, and expense of another trial for the same offense." Morris v. Mathews, 475 U.S. 237, 247 (1986). 
represent oneself is intended to have a therapeutic or dignitary function by enabling the defendant to participate in the proceedings against him. ${ }^{65}$ When a trial court has frustrated this truth-neutral function of the right by preventing an undeniably guilty defendant from representing himself, a new trial at which the defendant has the opportunity to represent himself can cure the wrong and will vindicate the right's intended function. Likewise, when a defendant has been indicted by a grand jury selected in a racially discriminatory fashion, convening a new grand jury that has been selected properly will protect the purposes of the right involved. ${ }^{66}$

In cases where redoing the adjudicative process can correct the damage constitutional error has wrought, it does not matter that the interests in finality and judicial economy favor upholding the conviction; these interests are simply insufficient to override the essential purposes of constitutional guarantees. ${ }^{67}$

3. The Role of Deterrence. - If a court were concerned only with remedying a particular error in a particular case, it would never reverse a conviction when constitutional error has not impaired a right's purpose or when the effect of constitutional error could not be repaired by retrial. A court's concerns must, however, extend beyond furnishing a remedy to the defendant in the particular case before it. Specifically, a court must be concerned with whether and to what extent the remedial rule it chooses will deter future violations of the constitutional right in question.

Deterrence becomes a relevant concern in two situations. First, when courts cannot effectively remedy the harm resulting from a particular type of constitutional error after the fact, they must attempt to minimize the occurrence of such errors. Only by deterring error in future cases can courts effectuate the values underlying constitutional rights falling into this category, such as fourth amendment rights and the fifth amendment privilege against self-incrimination.

Second, even when redoing the adjudicative process can repair the damage an error has already wrought, courts must use an overcompensatory sanction to prevent those errors that often escape detection. Our adversary system presumes that defense counsel will identify constitutional errors occurring on the record or in the presence of the defendant. Constitutional errors occurring off the record or outside the defendant's presence, however, may escape detection even though defense counsel performs adequately. Consider, for example, cases in which the prosecutor has knowingly used perjured testimony, ${ }^{68}$ or has

65. Faretta v. California, 422 U.S. 806, 820-21, 834 (1975); see infra notes 130-34 and accompanying text.

66. See infra notes 77-83 and accompanying text.

67. See supra notes 51-52 and accompanying text.

68. See, e.g., Mooney v. Holohan, 294 U.S. 103 (1935); Williams v. Griswald, 743

F.2d 1533 (11th Cir. 1984); United States v. Bigeleisen, 625 F.2d 203 (8th Cir. 1980); 
resorted to abusive tactics in secret grand jury proceedings. The facts establishing constitutional error of this type are typically known only to the prosecutor. Because the prosecutor has shown a willingness to abuse judicial processes, ${ }^{69}$ it is reasonable to conclude that he will actively conceal his actions and that a significant number of errors of this type will escape detection. To eliminate incentives to commit this type of error, courts must use a sanction that is sufficient to compensate for the probability that any given violation will remain undetected and unremedied. ${ }^{70}$

The appropriate level of deterrence varies, depending on which justification applies. Because sanctions such as reversing the conviction or barring reprosecution altogether entail significant social costs, courts should choose the minimum sanction necessary to protect a right's purposes.

When the probability that a given type of violation will be discovered is close to $100 \%$ and deterrence is relevant only because the adjudicative process cannot effectively repair damage wrought by a particular type of constitutional error, the Chapman rule seems to be an adequate deterrent. When constitutional error originates with the police or prosecutor, the Chapman rule will ensure that error does not aid these officials in obtaining a conviction. In this situation, because virtually all violations are detected, reversal will always occur when law enforcement officials needed the fruits of a violation to convict; reversal will not occur when it is clear beyond a reasonable doubt those fruits were not needed. Under Chapman, law enforcement officials will thus be unable to use error to obtain a conviction that they would not have been able to obtain without error. Chapman, however, does not completely eliminate all incentives to commit error because, first, law enforcement officials may be motivated to incarcerate a defendant until a reviewing court reverses, ${ }^{71}$ and, second, a prosecutor's chances of obtaining a valid conviction may in some circumstances be better at a

United States v. Barham, 595 F.2d 231 (5th Cir. 1979), cert. denied, 450 U.S. 1002 (1981).

69. See generally Arenella, Reforming the Federal Grand Jury and the State Preliminary Hearing to Prevent Conviction Without Adjudication, 78 Mich. L. Rev. 463, 539-57 (1980).

70. For examples of the growing body of literature on the considerations involved in devising legal rules that furuish an optimal level of deterrence, see Becker, Crime and Punishment: An Economic Approach, 76 J. Pol. Econ. 169 (1968); Posner, An Economic Theory of the Criminal Law, 85 Colum. L. Rev. 1193 (1985); Posner, Excessive Sanctions for Governmental Misconduct in Criminal Cases, 57 Wash. L. Rev. 635 (1982); Posner, Rethinking the Fourth Amendment, 1981 Sup. Ct. Rev. 49; Shavell, Criminal Law and the Optimal Use of Nonmonetary Sanctions as a Deterrent, 85 Colum. L. Rev. 1232 (1985).

7I. A defendant must bear a heavy burden-clear and convincing evidence that he will not flee and does not pose a danger to the community-to obtain a stay of his

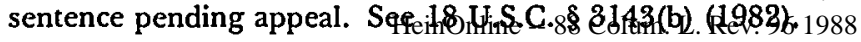


second trial. ${ }^{72}$ Yet in the eyes of a prosecutor, these potential benefits may well be outweighed by the time and expense of a retrial and the adverse effect of reversal on his professional reputation. Thus, it seems reasonable to suppose that Chapman, on balance, gives law enforcement officials a disincentive to commit error and use its fruits. If so, the Chapman rule sufficiently deters constitutional error which, though easy to detect, creates harm that is not remediable by redoing the adjudicative process. ${ }^{73}$

The relatively mild deterrence flowing from the Chapman rule, however, may well be insufficient when there is a significant probability that any given error of a particular type will escape detection. If prosecutors or police feel they stand a significant chance of escaping detection after committing constitutional error, they will likely conclude that the benefits from added convictions obtained with undetected constitutional violations outweigh the time, expense and embarrassment of the occasional reversal and retrial. This is especially true because the Chapman rule excuses errors committed in cases where the defendant would clearly have been convicted anyway; the prosecutors or police will suffer a reversal only where they might not have gained a conviction on legitimate grounds.

A rule of automatic reversal may create disincentives sufficient enough to deter constitutional violations even though they often remain undetected. Because law enforcement officials, upon committing error, presumably often do not know whether their case will become so strong that the error would have been declared harmless under Chapman, they face the possibility of an automatic reversal despite being able to prove guilt on wholly legitimate grounds. This seemingly significant disincentive may outweigh the benefits from convictions obtained through undetected constitutional violations.

Nevertheless, the expected probability that error will go undetected, if sufficiently great, will certainly cause the potential benefits from committing error to outweigh the potential harms. Consequently,

72. At a second trial, the prosecution will have advance knowledge of the precise nature of the defense. Inasmuch as the government has vastly superior investigative resources and the defendant usually is aware of the nature of the prosecutor's case even before the first trial, this knowledge increases the likelihood of a conviction.

73. The Chapman rule would also seem appropriate when the error originates with the judge rather than the prosecutor or police. In cases where the judge has intentionally engaged in misconduct, for instance, it is reasonable to suppose that he is motivated by a desire that the defendant be convicted. The Chapman rule ensures that the misconduct does not increase the chances of a conviction, thereby eliminating the incentive to engage in the misconduct. Moreover, the rule may even create disincentives by requiring the judge to sit through a retrial and to suffer the embarrassment of reversal.

The Chapman rule also deters negligent judicial error. Because the judge is aware that he may have to retry the case and suffer reversal, he will be induced to exercise care in ascertaining and honoring the defendant's rights. In addition, because the Chapman rule ensures that constitutional error is to the prosecution's disadvantage, it gives prosecutors an incentive to prevent the judge from lapsing into error. 
there may need to be a more severe sanction for types of constitutional error that often escape detection. The social costs of barring reprosecution after reversal of the conviction make such a bar an unattractive option. Consistent imposition of some sort of discipline upon the responsible officials, together with automatic reversal, may be the most appropriate way of deterring constitutional error that is difficult to detect. ${ }^{74}$

\section{B. Application of the Proposed Approach}

Although the Court's theory of harmless error does not accommodate truth-neutral or truth-impairing values, ${ }^{75}$ the Court surprisingly has chosen the proper remedial rule for many errors involving rights having clearly truth-impairing or truth-neutral purposes. Unlike the Court's approach, however, the framework outlined here yields a principled justification for these decisions. It is also surprising that some of the Court's decisions respecting truth-furthering rights are inconsistent with this framework and others are at least highly suspect. The problems stem from the Court's failure to consider the possibility that truth-furthering rights also have non-truth-furthering purposes, to articulate the reasons why courts are unable to measure the impact of a given type of violation on a case-by-case basis, and to consider the role of deterrence.

The approach proposed here does not yield easy solutions in every instance. ${ }^{76} \mathrm{~A}$ critical-and difficult-part of applying this approach requires courts to identify the fundamental purposes of the constitutional right at stake. The approach, however, does ensure that the choice of a

74. Courts sometimes suggest that considerations of "judicial integrity" furnish an independent justification for choosing a particular constitutional remedy. But judicial integrity, which seeks to ensure that results of the judicial process are not tainted by constitutional error, United States v. Calandra, 414 U.S. 338, 355-62 (1974) (Brennan, Douglas \& Marshall, JJ., dissenting), requires courts to reverse a conviction only when other considerations also compel reversal.

Judicial integrity obviously does not require that a defendant's conviction be reversed when constitutional error has not thwarted the purpose of the underlying right. A court can uphold the conviction without putting its imprimatur on any harm of constitutional significance. When, on the other hand, constitutional error has impaired a right's purposes, our theory requires either automatic reversal (when redoing the adjudicative process can repair the damage to the right's purposes) or application of the Chapman rule (to deter future violations if the damage cannot be repaired). Judicial integrity does not require more than this; it is adequately protected by the Chapman rule. When a court applying the Chapman rule concludes that constitutional error could not have affected the outcome, it in no way ratifies the error by affirming the conviction.

75. See supra notes 44-52 and accompanying text.

76. Obviously, this Article cannot develop the framework's application to each and every one of the constitutional rights that criminal defendants possess. The discussion is therefore limited to those rights that best illustrate how the approach proposed here differs from the Court's and how the adoption of this approach would change, justify or clarify existing law. 
remedial rule turns on a right's underlying values rather than on a conclusory characterization of the right as basic or not or on an unexamined conception of a "fair trial."

\section{Truth-Neutral or Truth-Impairing Rights.}

a. The Right to a Grand Jury Selected in a Race-Neutral Fashion. - This past Term, in Vasquez $v$. Hillery, ${ }^{77}$ the Supreme Court held that racial discrimination in the selection of the grand jury, a violation of a defendant's equal protection rights, is not rendered harmless by his subsequent conviction by a petit jury. The Court's reasoning was an unsatisfying and confusing melange of concerns for the fairness of the outcome, judicial integrity and deterrence. The majority in Vasquez appeared to view this equal protection right as based at least in part on a concern for the outcome of the grand jury process. ${ }^{78}$ It said, for instance, that the purpose of the grand jury is not only to ensure that the state's evidence supports a finding of probable cause that the defendant committed a crime, but also to select the severity and number of the offenses with which the defendant will be charged. ${ }^{79}$ In the majority's view, the right to be free from racial discrimination ensures that the values of all discrete racial groups are included in the grand jury process. In support of its decision to employ a per se rule of reversal, the Court reasoned that it could not be sure that the intentional exclusion of blacks had had no effect on the grand jury's charging decisions. ${ }^{80}$

In deciding whether the Vasquez majority was correct in focusing on the outcome, one must define the nature and purpose of the equal protection right at stake. A criminal defendant's equal protection right to object to race discrimination in the selection of his grand jury may be seen to derive from his right not to be indicted on the basis of his race. The reasoning may be that an improperly constituted grand jury creates an unacceptably high risk of a racially biased indictment. If the right is viewed in these terms, the Court should have focused more clearly on whether the defendant's subsequent conviction by a properly selected petit jury reduced the risk of a racially biased indictment to a constitutionally permissible level.

Alternatively, the nature of the equal protection right may be characterized as permitting members of racial minorities to participate in the criminal justice system on an equal footing with other racial groups. ${ }^{81}$ The exclusion of blacks from the grand jury, therefore,

77. 106 S. Ct. 617 (1986).

78. Id. at 623 (" $[E]$ ven if a grand jury's determination of probable cause is confirmed in hindsight by a conviction on the indicted offense, that confirmation in no way suggests that the discrimination did not impermissibly infect the framing of the indictment and, consequently, the nature or very existence of the proceedings to come.").

79. Id.

80. Id. at 624 .

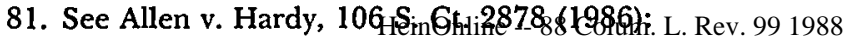


would infringe upon the equal protection rights of those blacks in the community who might have served, and not upon the defendant's rights. Under this theory, a defendant is given standing to enforce the rights of these persons because he is in a far better position to discover, and has a greater incentive to rectify, error. ${ }^{82}$

Conceived in this way, the purpose of the equal protection right at stake in Vasquez would seem to relate not at all to the grand jury's substantive charging decisions. Whether or not the discriminatory exclusion of blacks from the grand jury has an effect on the grand jury's charging decisions, exclusion violates the right's purpose of ensuring that minorities participate in governmental processes. Redoing that part of the process affected by the error, that is, permitting a grand jury selected in a race-neutral fashion to reconsider probable cause and possibly reindict the defendant, would cure the harm caused by the error. ${ }^{83}$

Whether the purpose of the equal protection right is viewed as safeguarding against a risk of a racially biased indictment or as ensuring the participation of minorities in the criminal justice system, our framework suggests that the Court adopted an unnecessarily broad remedy in Vasquez. The Court's remedy requires that a defendant's conviction be reversed and a new trial held whenever this kind of equal protection violation has occurred. Yet, however characterized, the harm caused by the equal protection violation can be undone simply by having a grand jury that is selected in a nondiscriminatory fashion reconsider the case. Because of the costs associated with retrial, the conviction should be

\footnotetext{
By serving a criminal defendant's interest in neutral jury selection procedures, the rule [prohibiting racial discrimination in the impanelment of the petit jury] may have some bearing on the truthfinding function of a criminal trial. But the decision serves other values as well. [It] ensures that States do not discriminate against citizens who are summoned to sit in judgment against a member of their own race and strengthens public confidence in the administration of justice.
}

Id. at 2880.

82. In Vasquez, the Court observed that although those who have been wrongly excluded from grand jury service in theory have a remedy under 42 U.S.C. $\$ 1983$, such suits are "extremely rare" because those excluded "are often without knowledge of the discriminatory practices and without incentive to launch costly legal battles to stop them." Vasquez, $106 \mathrm{~S}$. Ct. at 623 n.5. For discussions of the doctrine of third party standing, see Craig v. Boren, 429 U.S. 190 (I976); Barrows v. Jackson, 346 U.S. 249 (1953); Monaghan, Third Party Standing, 84 Colum. L. Rev. 277 (1984).

83. One can imagine some cases in which the harm caused by a violation of the right could not be cured by redoing the grand jury process. Suppose, for example, that the error occurred many years before the defendant discovers it, as was the case in Vasquez. By the time the defendant raises the error, the composition of the community from which grand juries were drawn many years earlier may have changed so significantly that redoing the process will not ensure that those originally excluded from the grand jury on the basis of their race will be in the pool from which the curative grand jury is selected. Even if this is the case, reversing the conviction may still be required by considerations of deterrence.HeinOnline -- 88 Colum. L. Rev. 1001988 
vacated only when the new grand jury declines to indict or decides to charge the defendant with different offenses.

The right to be free from race discrimination in the selection of a grand jury may also be seen to derive from a due process right to a representative grand jury instead of from equal protection. In contrast to the possible purposes of the equal protection right, the purpose of the due process right would be to ensure reliable factual determinations, to guard against prosecutorial overreaching, and to ensure that charging decisions conform to the community's fundamental sense of justice. In fact, this is essentially how the Vasquez majority viewed the purposes of the equal protection right. If the purposes of the right are construed this broadly, then the proper inquiry is, again, whether those purposes were impaired, and whether redoing the process can cure the resulting harm. A defendant's subsequent conviction by a petit jury ensures that the discrimination did not thwart the truth-furthering purpose of the right.

Finally, constitutional errors involving racial discrimination in the grand jury selection process might be especially difficult to detect, thus calling for added deterrence. This would depend primarily on whether the selection of the grand jury is open to inspection by defense counsel. If the level of detection is low, reversal would be appropriate regardless of whether a new grand jury does or would indict. Furthermore, if the Court is especially concerned about purging our criminal justice system of racial discrimination, reversal might be seen to communicate the appropriate message.

b. The Right Against Coerced Confessions. - The Court has said several times that admission of a coerced confession may never be considered harmless. ${ }^{84}$ Yet it has also held that the unconstitutional admission of other types of confessions may be held harmless. The Court has held, for instance, that the admission of a confession obtained in violation of the Massiah doctrine, which prohibits police from questioning a defendant after the right to counsel has attached, may be deemed harmless under the Chapman rule. ${ }^{85}$ Shortly after Chapman was

84. In Payne v. Arkansas, 356 U.S. 560, 568 (1958), a case decided before the advent of the doctrine of harmless constitutional error, the Supreme Court held that a conviction must be reversed when a coerced confession is introduced into evidence. The Court has cited Payne with approval in several more recent decisions. See, e.g., Rose v. Clark, 106 S. Ct. 3101, 3106 (1986); United States v. Hasting, 461 U.S. 499, 508 n.6 (1983).

85. Milton v. Wainwright, 407 U.S. 371 (1972). See infra note 96 and accompanying text.

Although the Supreme Court has never squarely addressed the application of Chapman to Miranda, lower federal courts have uniformly held that Miranda violations may constitute harmless error. See supra note 32 . They have been almost equally uniform in their failure to articulate any substantial reasons in support of this result. See, e.g., Null v. Wainwright, 508 F.2d 340, 343 (5th Cir.) (an automatic rule of reversal does not apply because Chapman did not specifically exempt Miranda violations from harmless error rule), cert. denied, 421 U.S. 970 (1975) But cf. Commonyealth v. Padgett, 428 
decided, the Court also held that the admission of a confession in violation of a defendant's right of confrontation may be harmless. ${ }^{\mathbf{8 6}}$

The Court has not attempted to resolve these tensions and has consequently caused considerable confusion in the lower courts. ${ }^{87}$ The Court's dictum supporting a rule of automatic reversal for coerced confessions cannot be defended on the ground that a confession always has a great impact on the jury. ${ }^{88}$ That rationale implies that, contrary to the Court's decisions, a rule of automatic reversal is likewise appropriate for confessions admitted in violation of.Massiah and the Confrontation Clause. Nor can the dictum regarding coerced confessions be justified by saying that their reliability is inherently suspect. ${ }^{89}$ The reliability of a confession made by a nontestifying codefendant admitted in violation of a defendant's right of confrontation is also suspect, for the defendant lacks an opportunity to cross-examine the codefendant and the codefendant has a clear incentive to minimize his own involvement by casting primary blame on others. The Court thus

Pa. 229, 236, 237 A.2d 209, 212 (1968) (Miranda violations may be held harmless because they do not affect the reliability of the fact-finding process).

86. See Harrington v. California, 395 U.S. 250 (1969).

87. Although most courts have followed the Court's declarations that coerced confessions are subject to an automatic rule of reversal, a few lower courts have applied the Chapman rule. See United States v. Murphy, 763 F.2d 202, 208-1 1 (6th Cir. 1985), cert. denied, 474 U.S. 1063 (1986); Harrison v. Owen, 682 F.2d 138, 140-42 (7th Cir. 1982); cf. State v. Castaneda, 150 Ariz. 382, 387, 724 P.2d 1, 6 (1986) (Assuming that defendant's statement was coerced, "any error in failing to suppress the statement was harmless beyond a reasonable doubt."). These cases cite Millon for the proposition that admission of an involuntary confession may be held harmless. In Millon, the defendant contended that one of his four confessions was involuntary and obtained in violation of his right to counsel. The Court assumed arguendo that the confession was inadmissible but held that, in view of the three other validly obtained confessions, the error was harmless beyond a reasonable doubt. On its face, Millon does seem to hold implicitly that admission of an involuntary confession may be harmless; otherwise, the Court would have had to decide the merits of the defendant's involuntary confession claim to uphold the conviction.

This reading of Milton, however, is inconsistent with the facts of that case, subsequent decisions of the Court and sound principles of constitutional decisionmaking. On the facts of Milion, the involuntary confession claim was patently without merit: the defendant had willingly confessed his role in the crime to a cellmate, who was in fact a police officer. The only colorable constitutional objection to admission of the confession was based on the Massiah doctrine, which holds that police may not question a defendant, surreptitiously or otherwise, once his right to counsel has attached. Millon, then, is properly read as holding that a Massiah violation may be held harmless. Surely the Court would not have overruled Payne without saying so and without giving any reasons. It is noteworthy that subsequent Supreme Court decisions continue to cite Payne approvingly. See supra note 84; cf. Neelley v. State, 494 So. 2d 669, 674 (Ala. Crim. App. 1985) (distinguishing between true "coerced" confession from confession obtained after violation of "police procedures"; only latter type of involuntary confession subject to Chapman rule), cert. denied, 107 S. Ct. 1389 (1987).

88. See Vargas v. Brown, 512 F. Supp. 271, 278 (D.R.I. 1981); Mause, supra note 11 , at $543-44$.

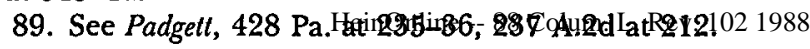


has not articulated a convincing rationale for its repeated declarations that the admission of a coerced confession requires automatic reversal. This is probably because the right against coerced confessions does not fit into the Court's truth-furthering model of harmless error jurisprudence..$^{90}$

A number of purposes have been attributed to the right against coerced confessions and the fifth amendment privilege against self-incrimination from which it derives. Judicial opinions and commentators variously assert that these protections seek to preserve a sphere of mental privacy, ${ }^{91}$ to prevent law enforcement officials from using abusive tactics, ${ }^{92}$ and to save the accused from cruelty and humiliation. ${ }^{93}$ Viewed in light of any of these purposes, the harm wrought by coercing a confession cannot be undone by redoing the judicial process. A new trial cannot restore a loss of privacy, undo abusive conduct or erase humiliation felt by the accused at the time of the coercion.

The remedial rule must therefore be concerned with deterring future violations rather than with curing the incurable harm that has already occurred. Furthermore, violations of the right against coerced confessions do not go undetected; the defendant necessarily witnesses them. Under the approach proposed here, the Chapman harmless error rule, which ensures that law enforcement officials do not benefit from constitutional error and embraces the modest deterrent of requiring a retrial when the error has influenced the result, is sufficient.

Although the purposes described above are those most frequently attributed to the right against coerced confessions and the privilege against self-incrimination, scattered references to other purposes can also be found. It is sometimes said that these protections are truthfurthering, that they reflect doubts concerning the reliability of involuntary confessions. ${ }^{94}$ Because the purpose of a truth-furthering right is

90. See Colorado v. Connelly, 107 S. Ct. 515, 522 (1986) (Exclusion of an involuntary confession withholds relevant evidence: " " $t]$ ]he aim of the requirement of due process is not to exclude presumptively false evidence, but to prevent fundamental unfairness in the use of evidence, whether true or false." ") (quoting Lisenba v. California, 314 U.S. 219, 236 (1941)).

91. See, e.g., Tehan v. Shott, 382 U.S. 406,416 (1966) (the privilege reflects "the concern of our society for the right of each individual to be let alone"); Murphy v. Waterfront Comm'n, 378 U.S. 52, 55 (1964) (privilege reflects "our respect for the inviolahility of the human personality and of the right of each individual "to a private enclave where he may lead a private life' ') (quoting United States v. Grunewald, 233 F.2d 556, 581-82 (1956) (Frank, J., dissenting)); see also Dolinko, Is There a Rationale for the Privilege Against Self-Incrimination, 33 UCLA L. Rev. 1063, 1066 n.19 (1986) (citing authority).

92. See, e.g., Miller v. Fenton, 474 U.S. 104, 109 (1985) (purpose of prohibition against involuntary confessions is to curb police conduct that is " "revolting to the sense of justice' ") (quoting Brown v. Mississippi, 297 U.S. 278, 286 (1936)).

93. See, e.g., Dolinko, supra note 91 , at 1066 n.18 (citing authority).

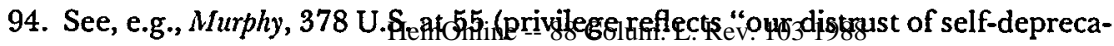


not impaired when a violation does not affect the outcome, the Chapman rule generally protects the right's purpose.

Although violation of a truth-furthering right must be subject to automatic reversal when one cannot be confident that a particular type of violation has not affected the outcome, this exception would not apply in the context of coerced confessions. It is true that the Court has suggested that a jury will inevitably be affected by incriminating words from a defendant's own mouth. ${ }^{95}$ This suggestion, however, is inconsistent with the Court's holdings that a confession obtained in violation of the Massiah doctrine or of a defendant's right of confrontation may be held harmless under Chapman. In Milton $v$. Wainwright, ${ }^{96}$ for instance, the Court held that a confession obtained in violation of Massiah was harmless in view of three other properly admitted confessions containing much the same information. Milton illustrates that a court sometimes can be confident that an improperly admitted confession could have had no reasonable impact on the verdict. The confession may be cumulative as a matter of law, as in Milton, for the remaining evidence may be so strong that any rational jury would be compelled to convict. Consequently, even if the right against coerced confessions is seen as a truth-furthering right, the Chapman rule is appropriate.

Finally, some authorities say that the privilege against self-incrimination implements "our sense of fair play which dictates a 'fair stateindividual balance ...." "97 If the purpose of the privilege is conceived as protecting a truth-neutral value in fair play, an automatic rule of reversal is appropriate. The harm caused by the violation-the skewed balance between the state and the accused-would be cured by a new trial at which the confession and its fruits are excluded. Because the value in fair play is not concerned with reliability, the conviction should be reversed and process redone even when the defendant is undeniably guilty and we are fully confident that the confession did not affect the jury's verdict.

The right against coerced confession illustrates the importance of identifying the nature of the values inhering in particular constitutional rights. The Supreme Court has simply asserted in conclusory fashion that a rule of automatic reversal should apply to errors involving this right because the right is among those rights "so basic to a fair trial that their infraction can never be treated as harmless error," 98 without considering whether the right's purposes require such a remedy.

tory statements"); Y. Kamisar, W. LaFave \& J. Israel, Modern Criminal Procedure: Cases, Comments and Questions 553-57 (5th ed. 1980).

95. See Jackson v. Denno, 378 U.S. 368, 383 (1964).

96. 407 U.S. 371 (1972).

97. Murphy, 378 U.S. at 55 (quoting 8 J. Wigmore, Evidence 317 (J. McNaughton rev. ed. 1961)).

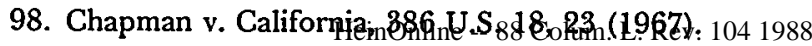


c. Fourth Amendment Rights. - The Court has adopted the Chapman test for fourth amendment violations, but bas not justified this result. ${ }^{99}$ The fourth amendment protects truth-impairing privacy interests against unreasonable governmental intrusion. 100 Once an unlawful invasion of privacy has occurred, however, a court cannot restore the loss of privacy by ordering a new trial at which the unconstitutionally seized evidence is excluded. ${ }^{101}$ Because it cannot redress the wrong in the case before it, a court can only seek to prevent future unconstitutional searches and seizures.

The Chapman rule adequately deters future violations of the fourth amendment. By reversing the conviction when there is a reasonable chance that illegally obtained evidence influenced the outcome, the rule eliminates any incentive for law enforcement officials to violate the fourth amendment. The remedial rule need not create strong disincentives to compensate for a significant risk of nondetection because there is no such risk in the context of fourth amendment violations. The existence of the illegally seized evidence alerts the defense to the violation. The mild sanction created by the Chapman rule would seem sufficient to deter.

The Chapman rule is also consistent with the level of deterrence contemplated by the exclusionary rule. If courts wished to maximize deterrence of fourth amendment violations, they would erect a complete bar to prosecution when law enforcement authorities have violated a defendant's fourth amendment rights. Courts, of course, do not resort to this extreme sanction. In deference to the government's interest in prosecuting crime, they merely exclude evidence obtained through the fourth amendment violation. Rather than maximizing deterrence, the exclusionary rule is designed to do no more than eliminate incentives to violate the Constitution. ${ }^{102}$

The Chapman rule likewise removes any incentive to use illegally seized evidence and may well create modest disincentives. Thus, if the exclusionary rule adequately protects the interest in individual privacy

99. See Chambers v. Maroney, 399 U.S. 42, 52-53 (1970); see also Rose v. Clark, 106 S. Ct. 3101, 3105 (1986) (citing Chambers for proposition that fourth amendment violations are subject to tbe Chapman rule).

100. E.g., Arizona v. Hicks, 107 S. Ct. 1149,1155 (1987) (" "There is nothing new in the realization that [tbe fourth amendment] sometimes insulates the criminality of a few in order to protect the privacy of us all.").

101. See Brown v. Illinois, 422 U.S. 590, 599-600 (1975) ("The [exclusionary] rule is calculated to prevent, not to repair. Its purpose is to deter-to compel respect for the constitutional guaranty in the only effectively available way-by removing the incentive to disregard it." ") (quoting Elkins v. United States, 364 U.S. 206, 217 (1960)) (emphasis added).

102. Kamisar, Police Practice Phases, supra note 5, at $270 \mathrm{n} .87$ ("Despite the popularity of the 'deterrence' terminology, it seems more accurate and useful to call the exclusionary rule a 'counterweight' within the criminal justice system or a 'disincentive'-a means of eliminating significant Hincentives for making illegal sfeasgeses. . . ."). 
that underlies the fourth amendment, the Chapman harmless error rule does so as well.

\section{Truth-Furthering Rights.}

a. The Right to Obtain Exculpatory Evidence in the Prosecutor's Possession. - In Brady v. Maryland, ${ }^{103}$ the Court held that a prosecutor has a constitutional duty to disclose exculpatory evidence in his possession. ${ }^{104}$ In subsequent cases, the Court has held that a defendant's conviction need not be reversed unless the undisclosed evidence creates a "reasonable probability" of a different outcome. ${ }^{105}$

At first blush, the Court would seem to be correct in requiring that a conviction be upheld when the undisclosed evidence could not reasonably have influenced the outcome. Because the Brady right is quintessentially truth furthering, its purpose is not infringed unless the undisclosed evidence may have affected the outcome of the criminal trial. ${ }^{106}$ Further, unlike the outright denial of counsel, the effect of a Brady error is not inherently difficult for a reviewing court to evaluate. A court will have all of the evidence presented at trial before it, and can consider its relationship to the undisclosed evidence. ${ }^{107}$

This analysis, however, overlooks the need to deter Brady violations. Because the facts establishing a Brady violation are exclusively within a prosecutor's possession, they are easily concealed from the defense. It is therefore likely that a significant share of constitutional errors involving the Brady right, whether intentional or negligent, are never uncovered. Unless courts impose an overbroad remedy when

103. 373 U.S. 83 (1963).

104. In particular, the Court held that "the suppression by the prosecution of evidence favorable to an accused upon request violates due process where the evidence is material either to guilt or to punishment irrespective of the good faith or bad faith of the prosecution." Id. at 87.

105. United States v. Bagley, 473 U.S. 667,682 (1985); United States v. Agurs, 427 U.S. 97, 112 (1976) (the omitted evidence must create a reasonable doubt that does not otherwise exist). These cases use an impact-on-the-outcome standard as a prejudice requirement to define the existence of the right itself rather than as a harmless error rule to decide the availability of a remedy. There is a close relationship between an outcomeoriented prejudice requirement and the Chapman harmless error rule; indeed, the Chapman harmless error rule can be restated as a prejudice requirement. See Bagley, 473 U.S. at 678; Saltzburg, supra note 11, at $1014 \mathrm{n} .88$. From the perspective of an appellate court, it makes no difference whether an impact-on-the-outcome standard is used as a prejudice requirement or as a harmless error rule. Under both rules, it will uphold the conviction unless the asserted violation had the requisite impact on the outcome.

For a discussion of whether courts should use an impact-on-the-outcome standard as a prejudice requirement, see infra notes $155-84$ and accompanying text.

106. See supra notes $56-58$ and accompanying text.

107. For an argument that a reviewing court cannot accurately assess the impact of undisclosed evidence, see Capra, Access to Exculpatory Evidence: Avoiding the Aglirs Problems of Prosecutorial Discretion and Retrospective Review, 53 Fordham L. Rev. 391,396 (1984). The Supreme Court has rejected this argument. Bagley, 473 U.S. at 682-83. 
they discover a violation, prosecutors will likely consider the benefits of such a violation-the enhanced likelihood of a conviction-to outweigh the likely costs of noncompliance with the Brady duty. Because prosecutors would never face reversal of a conviction they could have obtained without a Brady violation and because of the chance that a violation producing needed evidence will go undetected, the Chapman rule will not by itself create sufficient disincentives. Nor will a rule of automatic reversal add significantly to the disincentive. When the prosecutor decides whether to comply with Brady, he is generally well aware of the nature and strength of his evidence and knows whether his case is so strong that it can withstand the disclosure of exculpatory evidence. If it can, he has no reason to violate his Brady obligations. If it might not, his choice to enhance the possibility of conviction by violating Brady is influenced by the same disincentives under both the Chapman rule and the rule of automatic reversal: he will be reversed if caught. ${ }^{108}$

This discussion illustrates one of the consequences of the Court's failure to develop a coherent theory of harmless error. Because the Court has not recognized the independent significance of deterrence in the law of harmless error, it has adopted remedial rules that do not adequately deter Brady violations. This should be of great concern to the Court if it is serious about its rhetoric concerning the importance of factual reliability, for Brady directly implicates the reliability of the determination of gnilt.

b. The Right to Counsel. - Although the Court has often treated the right to counsel as only a truth-furthering right, ${ }^{109}$ it has not adopted the Chapman harmless error rule with respect to all aspects of the right. The Court has distinguished between cases involving outright denial of counsel and counsel whose performance is adversely affected by an $a c$ tual conflict of interest, on one hand, and cases involving all other kinds of ineffective assistance of counsel, on the other. A rule of automatic reversal applies in the former situations; ${ }^{110}$ an outcome-oriented preju-

108. See supra notes $68-74$ and accompanying text.

109. See, e.g., Strickland v. Washington, 466 U.S. 668, 685, 691-92 (1984); United States v. Cronic, 466 U.S. 648, 658 (1984). But see Kimmelman v. Morrison, 106 S. Ct. 2574,2586 (1986) ("we decline to hold either that the guarantee of effective assistance of counsel belongs solely to the innocent or that it attaches only to matters affecting the determination of actual guilt"); Flanagan v. United States, 465 U.S. 259, 268 (1984) (defendant's right to be represented by counsel of his choice may embody values other than "concern for the objective fairness of the proceeding"); Faretta v. California, 422 U.S. 806 (1975) (defendant has a constitutional right to represent himself even though self-representation generally impairs the reliability of the result). For a discussion of Faretta, see infra notes $130-34$ and accompanying text.

Because "it is through counsel that the accused secures his other rights," Kimmelman, $106 \mathrm{~S}$. Ct. at 2584, the view that the right to counsel has only truth-furthering purposes seems plainly wrong. The right, in part, is intended to secure other rights having non-truth-furthering purposes.

110. See Cuyler v. Sullivan, 446 U.S. 335, 350 (1980) (attorney whose performance is adversely affected by actual conflict of interest); Gideon v. Wainwright, 372 U.S. 335, 
dice test that is analogous to the Chapman rule in the latter. ${ }^{111}$

The Court has never provided a satisfactory explanation for these distinctions, ${ }^{112}$ and lower courts have been uncertain as to what the Court's right-to-counsel decisions imply with respect to errors involving certain aspects of the right to counsel. In particular, lower courts have divided over whether to treat orders denying a defendant the right to consult with his counsel for a brief period during trial as reversible per se or as subject to the Chapman rule. ${ }^{13}$

Accepting for a moment the view that the right to counsel is designed only to promote reliability, the theory proposed here suggests that the Chapman rule is the appropriate remedy for errors involving that right unless it is inherently difficult to show that a violation of the right affected the outcome. This difficulty exists when a defendant has been denied counsel altogether. A court is unable to evaluate the effect that the denial of counsel has had on the outcome because it lacks the information necessary to form an intelligent judgment: the record does not contain evidence and argument that an attorney would have developed. Yet this logic also applies when defense counsel was constitu-

345 (1963) (complete denial of counsel), cited with approval in Rose v. Clark, 106 S. Ct. 3101,3106 (1986).

111. See Strickland, 466 U.S. 668. Under this prejudice requirement, the defendant must show that but for his attorney's objectively unreasonable performance there is a "reasonable probability" the result would have been different. Id. at 694. "A reasonable probability is a probability sufficient to undermine confidence in the outcome." Id.

112. The Court has suggested that automatic reversal is appropriate in "circumstances that are so likely to prejudice the accused that the cost of litigating their effect in a particular case is unjustified." Cronic, 466 U.S. at 658; accord Strickland, 466 U.S. at 692. The likelihood of prejudice, however, does not differentiate the situation in which defense counsel has unreasonably failed to investigate possible defenses, where the Court requires the defendant to show outcome-influencing prejudice, from situations involving denial of counsel altogether or counsel suffering from an actual conflict of interest, where prejudice is presumed and a rule of automatic reversal applies. The mere physical presence of an attorney who does nothing to develop and support possible defenses does not magically reduce the likelihood of prejudice. Cf. Holloway v. Arkansas, 435 U.S. 475, 489 (1978) (physical presence of attorney suffering from an actual conflict of interest does not justify departure from rule of presumed prejudice).

113. In Geders v. United States, 425 U.S. 80 (1975), the Supreme Court held that an order prohibiting counsel from conferring with the defendant during an overnight recess violated the sixth amendment guarantee of counsel. Geders has been interpreted as adopting a rule of automatic reversal for such violations. Cronic, 466 U.S. at 659 n.25; Mudd v. United States, 798 F.2d 1509, 1513 (D.C. Cir. 1986). Courts disagree about whether the conviction must also be reversed automatically when a court has precluded the defendant from consulting with his attorney during a brief recess. Compare Crutchfield v. Wainwright, 803 F.2d 1103 (11th Cir. 1986) (en banc) (adopting rule of automatic reversal), cert. denied, 107 S. Ct. 3235 (1987) with United States v. DiLapi, 651 F.2d 140, 148-49 (2d Cir. 1981) (defendant required to show outcome was affected), cert. denied, 455 U.S. 938 (1982) and State v. Perry, 278 S.C. 490, 490-95, 299 S.E.2d 324, 325-26 (same), cert. denied, 461 U.S. 908 (1983); cf. Green v. Arn, 809 F.2d 1257, 1261-62 (6th Cir. 1987) (divided panel) (rule of automatic reversal applies when counsel has not attended partia(triial)-88 Colum. L. Rev. 1081988 
tionally ineffective in failing to investigate the case, ${ }^{114}$ a situation in which the Court has demanded that a defendant satisfy an outcomeoriented prejudice requirement. ${ }^{115}$ Under our theory, a rule of automatic reversal is appropriate in both situations.

In contrast, it is easier for a court to evaluate whether an actual conflict of interest that has adversely affected counsel's representation may reasonably have affected the outcome. Given the discretionary and multifaceted nature of the judgments attorneys routinely make and the impossibility of assigning precise and unitary motives to these complex judgments, the real difficulty would seem to lie in showing that a conflict has adversely affected the attorney's performance. Indeed, the Court has declared that it "would be virtually impossible" to "assess the impact of a conflict of interests on the attorney's options, tactics, and decisions."116 The Court, however, rather anomalously requires a defendant to show that the conflict adversely affected his attorney's performance and relieves him only of the burden of proving that the conflict could have influenced the outcome. ${ }^{117}$ But once a defendant has isolated how an actual conflict has adversely affected his attorney's performance, it should not be so difficult for him to articulate, and a court to evaluate, the impact of the conflicted representation on the outcome that a rule of automatic reversal must be used. This is not to suggest that it is fair to require a defendant to show adverse effect on performance. Rather, the point is that if this showing is required, it makes little sense to presume conclusively that this adversely affected performance influenced the outcome.

If one views the right to counsel solely as a truth-furthering right, rule of automatic reversal is clearly unjustified when a court has erroneously ordered a defendant not to consult with his attorney for a brief period during trial. Because the defendant and his counsel can inform the court of what they would have discussed, ${ }^{118}$ it should be relatively easy for courts to evaluate the possible impact of the order on the out-

114. See Cornell Note, supra note 11 , at 557.

115. See supra note 111 and accompanying text.

116. Holloway, 435 U.S. at 491.

117. In Cuyler v. Sullivan, 446 U.S. 335 (1980), the Court held that "[i]n order to demonstrate a violation of his Sixth Amendment rights, a defendant must establish that an actual conflict of interest adversely affected his lawyer's performance." $1 d$. at 350. This standard requires more than just a showing of how the conflict might have affected the attorney's performance; it requires that a defendant establish how that performance actually was adversely affected by the conflict.

118. One court reasoned that requiring a defendant to show how the order prejudiced him "would create an unacceptable risk of infringing on the attorney-client privilege." Mudd v. United States, 798 F.2d 1509, 1513 (D.C. Cir. 1986). The Supreme Court has implicitly rejected this reasoning. A defendant may be forced to reveal privileged communications to establish that his attorney was constitutionally ineffective under the Strickland standard or that his attorney's performance was adversely affected by an actual conflict of interest, as required by Cuyler. See supra notes 110-11 and accompanying text. 
come. This suggests that those lower courts applying the Chapman rule rather than a rule of automatic reversal to this particular constitutional error have reached the better result. ${ }^{119}$

c. The Right to Present Evidence. - The right to present evidence ${ }^{120}$ encompasses a number of constituent rights, including the rights of a defendant to confront adverse witnesses, ${ }^{121}$ to attend the trial, ${ }^{122}$ to testify on his own behalf, ${ }^{123}$ to be represented effectively by counsel ${ }^{124}$ and to compel the attendance of favorable witnesses. ${ }^{125}$ The Supreme Court has said that the purpose of these rights is to ensure the reliability of guilty verdicts. ${ }^{126}$ Except in a few situations relating to the right to counsel, ${ }^{127}$ it has held that violations of these rights may be held harmless. ${ }^{128}$

119. If the right to counsel also has truth-neutral purposes the Chapman rule may not be appropriate. See infra notes 120-36 and accompanying text.

120. In the leading case of Washington v. Texas, 388 U.S. 14 (1967), the Supreme Court described the right to present evidence, often called the right to present a defense, as follows:

The right to offer the testimony of witnesses, and to compel their attendance, if necessary, is in plain terms the right to present a defense, the right to present the defendant's version of the facts as well as the prosecution's to the jury so it may decide where the truth lies. Just as an accused has the right to confront the prosecution's witnesses for the purpose of challenging their testimony, he has the right to present his own witnesses to establish a defense. This right is a fundamental element of due process of law.

Id. at 19; see also Crane v. Kentucky, 106 S. Ct. 2142, 2146 (1986). See generally Clinton, The Right to Present a Defense: An Emergent Constitutional Guarantee in Criminal Trials, 9 Ind. L. Rev. 713 (1976); Westen, Confrontation and Compulsory Process: A Unified Theory of Evidence for Criminal Cases, 91 Harv. L. Rev. 567 (1978); Westen, Compulsory Process II, 74 Mich. L. Rev. 191 (1975); Westen, The Compulsory Process Clause, 73 Mich. L. Rev. 71 (1974) [hereinafter Compulsory Process I].

121. U.S. Const. amend. VI; e.g., Davis v. Alaska, 415 U.S. 308, 315-18 (1974).

122. Illinois v. Allen, 397 U.S. 337, 342-43 (1970).

123. Rock v. Arkansas, 107 S. Ct. 2704, 2708-10 (1987).

124. Strickland v. Washington, 466 U.S. 668,686 (1984).

125. Washington v. Texas, 388 U.S. 14, 18 (1967).

126. See, e.g., Crane v. Kentucky, 106 S. Ct. 2142, 2147 (1986) ("[E]xclusion of this kind of exculpatory evidence deprives a defendant of the basic right to have the prosecutor's case encounter and 'survive the crucible of meaningful adversarial testing.' ") (quoting United States v. Cronic, 466 U.S. 648, 656 (1984)).

127. See supra notes $109-19$ and accompanying text.

128. Crane, 106 S. Ct. at 2147 (remanding to state court for harmless error determination); Delaware v. Van Arsdall, 106 S. Ct. 1431, 1438 (1986) (violation of confrontation clause may be held harmless under the Chapman rule); Rushen v. Spain, 464 U.S. $114,117-18$ (1983) (per curiam) (denial of right to be present at trial subject to Chapman rule). Regarding some aspects of the right to present a defense, the Court has imposed an analogous prejudice requirement to define the very existence of the right in question. See Pennsylvania v. Ritchie, 107 S. Ct. 989, 1002 (1987) (discovery rights); United States v. Bagley, 473 U.S. 667, 678 (1985) (same); Strickland, 466 U.S. at 693 (right to effective assistance of counsel); United States v. Valenzuela-Bernal, 458 U.S. 858, 873 (1982) (right to interview witnesses deported by the government). This standard requires that the defendant establish that the evidence he seeks creates a "reasonable probability" of a more favorable outcome. Bagley, 473 U.S. at 682 . For a discussion of the relationship 
If the Court's view of these rights' purpose is correct, it has properly chosen to apply the Chapman harmless error rule rather than a rule of automatic reversal. The preconditions for application of the Chapman rule are all present: an outcome-oriented rule accurately gauges whether an error has impaired the purpose of the right; it is not inherently difficult to determine in a particular case whether an error may have affected the outcome; and redoing the adjudicative process can cure the harm caused by the error. ${ }^{129}$

The flaw in the Court's analysis is that it adopts too narrow a view of the purposes of the rights constituting the right to present evidence. Certainly these rights are archetypal truth-furthering rights: they directly contribute to the reliability of the outcome. One can argue, however, that they also incorporate a truth-neutral value in affording the defendant his day in court.

The Supreme Court's decision in Faretta $v$. Califormia ${ }^{130}$ supports the notion that the right to present evidence incorporates a truth-neutral value of participation. In Faretta, the Court held that a criminal defendant has a constitutional right to represent himself if he so chooses. The Court found the right of self-representation to be implicit in the sixth amendment's "statement of the rights necessary to a full defense," which includes the rights to counsel, to confront adverse witnesses and to compel the testimony of favorable witnesses. ${ }^{131}$ As the Court itself recognized, the right to self-representation cannot be explained in terms of truth-furthering values; a defendant's assertion of the right will generally impede the search for the truth. ${ }^{132}$ Rather,

between the Chapman rule and prejudice tests, see infra notes 155-84 and accompanying text.

129. See supra notes 55-74 and accompanying text.

130. 422 U.S. 806 (1975).

13I. Id. at 818 .

132. Id. at 832-34. In Flanagan v. United States, 465 U.S. 259 (1984), the Court suggested that the "right [to counsel of choice] reflects constitutional protection of the defendant's free choice independent of concern for the objective faimess of the proceeding." Id. at 267-68 (emphasis added). 1t reasoned that, as with the denial of the defendant's right to represent himself, a rule of automatic reversal may be required to protect the nontruth-furthering values protected by the right. Id.; see also McKaskle v. Wiggins, 465 U.S. $168,177 \mathrm{n.8}$ (1984) (suggesting, in dictum, that the right of self-representation may not be held harmless because it protects values unrelated to truth determination).

Federal appellate courts have adopted Flanagan's suggestion, holding that the denial of a defendant's right to counsel of choice requires reversal of the conviction regardless of whether the outcome was thereby affected. United States v. Diozzi, 807 F.2d 10, 16 (1st Cir. 1986); Wilson v. Mintzes, 761 F.2d 275, 286 (6th Cir. 1985); see also Johnstone v. Kelly, 808 F.2d 214, 216-19 (2d Cir. 1986) (denial of right of self-representation may not be held harmless) (citing cases).

The Supreme Court's suggestions in Flanagan, which are logically implied by Faretta, are difficult to reconcile with the Court's other right to counsel decisions. If the sixth amendment implies a right to counsel of choice that embraces non-truth-furthering values, it would seem that other aspects of the right to counsel should be interpreted in light of these same values. See supra notes 109-19 and accompanying text. 
the right exists in large part to "affirm the dignity and autonomy of the accused"133 by giving him a measure of control over the proceedings. ${ }^{134}$

Because the right of self-representation derives from the various rights forming the right to a full defense, Faretta necessarily implies that the same truth-neutral value also underlies the parent rights. Indeed, the Court's decision in Faretta implies that the truth-neutral value in participation underlying the right to present evidence outweighs that right's truth-furthering value when the two values conflict. For if the truth-furthering value predominated, the right of self-representation would be acknowledged only when a court could be sure that it would not impede the search for the truth. Faretta, however, holds that the right of self-representation exists despite its truth-impairing effects.

But even beyond Faretta, each of the various rights constituting the right to present evidence-the rights to counsel, to confront adverse witnesses, to compulsory process, to testify and to attend trial-itself enables a criminal defendant to participate in the proceedings against him. Rather than existing as an unintentional by-product of these various rights' truth-furthering purpose, this participatory or dignitary function may be seen to have a constitutional significance of its own.

Although the specific nature of the value of participation may be difficult to define, at a minimum it bestows a certain dignity on all defendants. The Constitution rightly treats the accused as a person worthy of respect. Consequently, a defendant is entitled to have his voice heard in the proceedings in which his fate is decided, even if he has no reasonable chance of swaying a jury. Just as a citizen holding views that have no hope of prevailing has a right to participate in the political process, so also does an undeniably guilty criminal defendant have a right to participate in his criminal trial. Wholly apart from its effect on the truth-determining process, participation serves to "generat[e] the feeling, so important to popular government, that justice has been done." 135

Despite pervasive indications that the right to present evidence has truth-neutral as well as truth-furthering purposes, the Court's approach to errors involving the right, by focusing only on the truth-furthering values protected by the harmless error rule, blinds it to the right's truth-neutral values. This oversight is regrettable, for the Chapman test does not adequately protect the truth-neutral value in participation. ${ }^{136}$

133. McKaskle, 465 U.S. at 176-77.

134. Id. at 174.

135. Joint Anti-Fascist Refugee Comm. v. McGrath, 341 U.S. 123, 171-72 (1951) (Frankfurter, J., concurring); see also Carey v. Piphus, 435 U.S. 247, 260-64 (1978) (procedural due process serves a participatory function that is independent of its truthdetermining function); Codd v. Velger, 429 U.S. 624, 636 (1977) (Stevens, J., dissenting) (same).

136. The Court has itself recognized that the Chapman rule does not adequately 
An asserted constitutional error may have prevented the defendant from meaningful participation in the criminal process even though the outcome was not thereby affected. The truth-neutral value in participation does not necessarily mean that a harmless error rule must be rejected altogether. It does mean, however, that a harmless error rule must be framed so as to give truth-neutral values their due. Because a new trial can vindicate the right's participatory purpose, one must be granted despite the soundness of the conviction whenever that purpose has been frustrated.

d. Right to a Public Trial. - In Waller $v$. Georgia, ${ }^{137}$ the Supreme Court held that a Georgia court violated the defendant's qualified sixth amendment right to a public trial by excluding the public from a lengthy suppression hearing. Although the purposes of the right identified by the Court were all truth furthering, the Court adopted a rule of automatic reversal of sorts. In a brief paragraph addressing the issue of the appropriate remedy, the Court declined to vacate the defendant's conviction, but it did require the trial court to hold another suppression hearing. ${ }^{138}$ It squarely rejected the Chapman rule, which would have required a new suppression hearing only if closure affected the court's decision to admit the challenged evidence. ${ }^{139}$

Although the Chapman rule should be presumptively appropriate for rights having only truth-furthering purposes, automatic reversal is appropriate when it is exceedingly difficult to evaluate the effect of the type of error in question on the outcome. Violations of the right to a public trial generally fit into this exceptional class of truth-furthering rights. The right to a public trial is designed in part to discourage perjury and to encourage witnesses to come forward. ${ }^{140}$ A court would have to engage in ungnided speculation to conclude that the nonpublic nature of the proceeding had no effect on the witnesses' testimony or on which witnesses came forward to testify. The very nature of "the benefits of a public trial" is that they are "frequently intangible, difficult to prove, or a matter of chance." 141 Due to the difficulty of evaluating the effect of a nonpublic proceeding on the outcome, a rule of automatic reversal is thus generally appropriate. ${ }^{142}$

protect the participatory value underlying the right to self-representation. McKaskle, 465 U.S. at 177 n.8.

137. 467 U.S. 39 (1984).

138. Id. at $49-50$.

139. Id. at 49 n.9.

140. Id. at 46.

141. Id. at 49 n.9.

142. Our approach suggests two narrow exceptions to the general approach requiring automatic reversal. The first exists when disputed issues of fact are not relevant to any decisions made in the closed proceeding; the second when a defendant has contested in a closed proceeding the credibility of a government witness who later repeats the same testimony at an open hearing (such as at trial). In the first situation, courts can be confident that closure did not impair the truth-furthering values underlying the right. 
The per se rule utilized in Waller can also be justified if the right is seen in part to enable a defendant to air publicly his complaints about the government and society and in part to project an image of legitimacy and impartial justice. If these are indeed two purposes of the right, then in denying the defendant the intended public forum, the trial court has failed to promote them. Redoing the trial can restore the losses caused by the violation and vindicate the purpose of the right.

e. Right to an Impartial Tribunal. - The Supreme Court has characterized the right to an impartial tribunal as a basic right whose denial requires reversal. ${ }^{143}$ The approach suggested here, ${ }^{144}$ however, implies that the Court's dictum concerning the appropriate remedy for error involving this right is correct only if the right is seen to embody non-truth-furthering purposes.

If the right to an impartial tribunal is viewed solely as a truth-furthering right, ${ }^{145}$ the use of an automatic reversal rule is unjustified. The Chapman rule must be used for errors involving rights having only truth-furthering purposes unless, first, it is inherently difficult to ascertain in particular cases whether this type of violation has affected the outcome or, second, the remedial rule must compensate for a significant risk that errors of this sort escape detection. The right to an impartial tribunal fits within neither exception.

Language in the Court's opinions suggests that a rule of automatic reversal is appropriate because one can never know whether the biases of a judge or a juror have influenced the outcome of a particular case. ${ }^{146}$ Yet, though it may be impossible for a defendant to prove that partiality did affect the outcome, the prosecutor can in many cases prove that the violation did not affect the outcome. Unlike denial of the right to counsel, a violation of the right to an impartial tribunal does not unduly restrict the evidence that is available to a reviewing court. A

Because no facts are in dispute, there are no witnesses to encourage to come forward and no perjury relevant to the proceedings to discourage. The second situation is more complex. Although closure of the first hearing might have had an impact on the truthfulness of the witness' testimony, he has already repeated his testimony in a public proceeding and there would be no point in requiring that he do so yet again.

143. The Court has said repeatedly that a violation of the right to an impartial tribunal may never be declared harmless. See, e.g., Rose v. Clark, 106 S. Ct. 3101, 3106 (1986); United States v. Hasting, 461 U.S. 499, 508 \& n.6 (1983). In Gray v. Mississippi, 107 S. Ct. 2045 (1987), the Court held squarely that the erroneous exclusion for cause of a "death qualified" juror from a sentencing jury that imposed the death penalty is subject to a rule of automatic reversal. Id. at 2056 . A four Justice plurality viewed the right in question as an aspect of the right to an impartial jury, which "goes to the very integrity of the legal system" and as to which "the Chapman harmless error analysis cannot apply." Id.

144. See supra notes $64-67$ and accompanying text.

145. See Smith v. Phillips, 455 U.S. 209, 224-25 (1982) (Marshall, Brennan, Stevens, J.J., dissenting) (right to an impartial jury aimed at ensuring reliable determina-

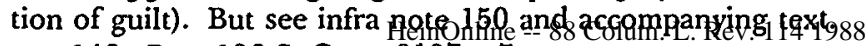

146. Rose, $106 \mathrm{~S}$. Ct. at 3107 n.7. 
reviewing court has all of the evidence and argument an impartial decisionmaker would have had before it. It is true that a court has no reliable means of determining whether the particular jury or judge was influenced by partiality. But a court should nevertheless be able to discern when any rational decisionmaker would have been compelled to convict. If a rational decisionmaker would have been so compelled, the reviewing court can conclude that the error was harmless. The difficulty of showing that a violation has affected the outcome does not necessitate rejection of the Chapman rule; it merely requires that the prosecution bear the burden of demonstrating that the error did not undermine the reliability of the result. ${ }^{147}$

Considerations of deterrence do not require a rule of automatic reversal. The right to an impartial tribunal is most often infringed because jurors do not adequately disclose the facts indicating their possible biases. Even assuming that the risk of nondetection is sufficient to implicate a concern for deterrence, a rule that vacates the conviction or bars reprosecution will have no impact whatsoever on jurors. Unlike law enforcement officials and "compliant" judges, ${ }^{148}$ jurors have no personal or professional stake in convicting a defendant or avoiding reversal and retrial. As for those errors involving judicial partiality, the risk of nondetection is probably insufficient to justify a deterrencebased rule. Judges usually do not conceal the facts that give rise to the claim of partiality; it is the legal consequences of those facts that are in question.

One might object to the foregoing analysis on the ground that the right to an impartial tribunal fosters the appearance as well as the reality of a reliable result. This argument, however, does not justify application of a per se rule of reversal. If a rational decisionmaker would have been compelled to convict, a reasonable appearance of an unreliable result simply does not exist. ${ }^{149}$

The only truly substantial objection to using the Chapman rule is that the purposes of the right to an impartial tribunal extend beyond that of promoting the reliability of the determination of guilt. Under this view, the right to an impartial tribunal exists because otherwise the judicial process would offend the dignity of the accused and society's sense of fair play. ${ }^{150}$ If the right to an impartial tribunal incorporates

147. Admittedly, permitting a court to uphold a conviction when a rational jury would have been compelled to convict ostensibly conflicts with the prohibition against directed guilty verdicts and its underlying policy of permitting the jury to nullify the law. The Chapman rule can be formulated, however, in a manner that is consistent with the concept of jury nullification. See infra notes 220-35 and accompanying text.

148. See Duncan v. Louisiana, 391 U.S. 145, 156 (1968).

149. See supra note 43 .

150. The cases furnish some support for this view of the right's purposes. See Gray v. Mississippi, 107 S. Ct. 2045, 2057 (1987) (right to impartial jury is in part a "right not to have [one's] culpability determined by a 'tribunal "'organized to convict." " ") (quoting Witherspoon v. Illinois, 391 U.S. 510,521 (1968)); Marshall v. Jerrico, Inc., 446 U.S. 
such truth-neutral values, the approach suggested here requires a rule of automatic reversal, though not for the reasons the Court has advanced. These values may be frustrated even though we can be confident of the defendant's guilt. Because redoing the judicial process can effectuate the right's purposes of fostering individual dignity and ensuring fair play, these purposes require that the conviction be set aside and the process redone. ${ }^{151}$

f. Due Process Right to a Jury Instruction on Each Element of the Offense. - Lower courts have divided on whether a trial court's failure to instruct the jury on an element of the crime may be deemed harmless. ${ }^{152}$

238, 242 (1980) (right exists, in part, to promote "participation and dialogue by affected individuals in the decisionmaking process"); Mayberry v. Pennsylvania, 400 U.S. 455, 466 (1971) (vacating defendant's convictions for contempt even though Court viewed acquittal as inconceivable).

151. It should be noted that the right to an impartial jury may have truth-neutral purposes that are not shared by the right to an impartial judge. Unlike judges, jurors are not expected to be entirely rational agents who find facts and apply the law to the facts with antiseptic precision. One of the purposes of the right to a jury trial is to bring ordinary laypersons' sense of justice to bear on the case. Juror partiality may interfere with this function of the jury, which is frequently referred to as jury nullification. For the relationship between the Chapman rule and jury nullification, and an argument that the two are not necessarily inconsistent, see infra notes 220-35. The result in Gray, $107 \mathrm{~S}$. C. at 2045, may reflect similar concerns.

152. Compare Hoover v. Garfield Heights Mun. Ct., 802 F.2d 168, 177 (6th Cir. 1986) (failure to instruct jury on essential element of the offense not subject to harmless error rule), cert. denied, 107 S. Ct. 1610 (1987) with Redding v. Benson, 739 F.2d 1360 (8th Cir. 1984) (failure to instruct jury on essential element of offense may be held harmless), cert. denied, 469 U.S. 1222 (1985). The Supreme Court's decision in Rose v. Clark, 106 S. Ct. 3101 (1986), sent conflicting siguals as to the proper resolution of this issue. In Rose, the Court had held that a jury instruction that unconstitutionally shifts the burden of persuasion from the prosecution to the accused on a material element of the offense may be held harmless. In dictum, however, the Court declared that "harmless-error analysis presumably would not apply if a court directed a verdict for the prosecution in a criminal trial by jury." Id. at 3106 . In Hoover, a divided panel of the Sixth Circuit reasoned that a complete failure to instruct the jury on a material element of the offense is akin to a directed verdict on that issue. Hoover, 802 F.2d at 177-78. The dissent found the failure to instruct more analogous to the instructional error at issue in Rose. Id. at 180.

In Pope v. Illinois, 107 S. Ct. 1918 (1987), the Supreme Court resolved a related issue involving a failure to instruct the jury properly on an element of the crime. In a prosecution for distribution of obscene materials, the jury was told-erroneously, according to the Court-to consider the social value of the allegedly obscene materials under prevailing community standards rather than the standard of "a reasonable person." Pope, $107 \mathrm{~S}$. Ct. at 1921. The instruction itself amounted to constitutional error because it did not properly reflect the first amendment's definition of unprotected obscene materials. The Court, in an opinion joined by five Justices, held that although the instruction on this element of the offense was in error, the error could be deemed harm. less if no properly instructed rational juror could have found in the defendant's favor on this element. The Court's opinion, however, was careful to note that the jurors "were not precluded from considering the question of value," Pope, $107 \mathrm{~S}$. Ct. at 1922, and thus does not reach cases in which the jury has ngt received any instruction at all on an element of the offense. The four dissenting Justices thought that the Chapman rule 
Under the approach suggested here, the Chapman rule is presumptively appropriate for such rights. The purpose of the due process right to have the jury instructed that it must find each element of the charged crime beyond a reasonable doubt is truth furthering in nature. Moreover, the considerations that justify use of a rule of automatic reversal for truth-furthering rights do not apply to this particular right.

First, it is not difficult for a court to ascertain that a failure to instruct on a material element could have had no reasonable effect on the outcome of the proceeding. The error does not affect the composition of the record, and the court can determine whether the evidence as to the element was so compelling that any rational jury would find its existence beyond a reasonble doubt. ${ }^{153}$ Although permitting a court to make this determination is ostensibly inconsistent with the prohibition against directed guilty verdicts, the Chapman rule can be formulated in a manner that is consistent with this prohibition. ${ }^{154}$ Second, considerations of deterrence do not require automatic reversal. Because the failure to instruct occurs in the presence of the defendant and his counsel, the remedial rule need not compensate for a siguificant risk of nondetection.

\section{Defining Rights at Trial: The Limitations of an Impact-on-the-OUtCome Prejudice Test}

In defining the parameters of those rights composing a defendant's constitutional right to obtain and present evidence, ${ }^{155}$ courts have used rules focusing on outcomes in two different ways. ${ }^{156}$ They have adopted an outcome-oriented prejudice test at trial to trigger the very existence of some rights. For example, the government has a constitutional obligation to disclose exculpatory evidence to the defense only if the evidence in question creates a reasonable probability of an outcome more favorable to the defense. In contrast, courts have defined other rights at trial less strictly, confining an impact-on-the-outcome standard

should not apply in any circumstances to a failure to instruct the jury properly on the elements of the offense. Pope, 107 S. Ct. at 1925 (Stevens, J., dissenting).

153. See, e.g., Redding, 739 F.2d at 1363 (although court failed to inform the jury that to convict the defendant of the charged theft it was required to find that he had stolen property worth more than $\$ 1,000$, the property he allegedly had stolen was indisputably worth $\$ 12,000)$.

154. See infra notes $220-35$ and accompanying text.

155. Although the rights composing the right to obtain and present evidence should be recognized to have, in part, a truth-neutral function, see supra notes 120-36 and accompanying text, the Supreme Court largely treats these rights as having only a truth-furthering function and has applied impact-on-the-outcome standards to alleged constitutional errors. This Part, by criticizing the Court's choice between two impacton-the-outcome standards, can be seen as an additional criticism.

156. See United States v. Bagley, 473 U.S. 667, 678-80 (1985) (noting that the Chapman test, a remedial rule, can easily be translated into a definitional rule as a preju-

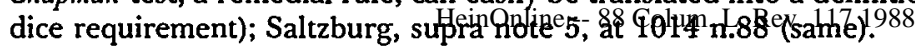


to a harmless error rule used on appeal or collateral review. To establish at trial a constitutional right to cross-examine a government witness for bias, for example, a defendant ordinarily need not show that the cross-examination may reasonably affect the outcome in his favor. The "prejudice" necessary to trigger the existence of the right at trial exists when the cross-examination may elicit evidence from a government witness tending to show bias. Whether the cross-examination may have affected the outcome comes into play only on appeal or in a habeas proceeding when a reviewing court determines whether an erroneous restriction of the right is harmless under Chapman. Thus, the difference between these two approaches is that one uses an impact-onthe-outcome standard at trial to determine the existence of a given right while the other employs a more relaxed test at trial, using an impact-on-the-outcome standard only as a post-trial harmless error rule.

On appeal or in a habeas corpus proceeding, little turns on the choice between these two uses of an impact-on-the-outcome standard. ${ }^{157}$ If, for instance, a defendant has been denied a requested opportunity to cross-examine a witness for bias but the cross-examination had no reasonable chance of affecting the outcome, and the existence of the right to cross-examine were to depend on its effect on the outcome, an appellate or habeas court would uphold the conviction on the ground that no constitutional violation had occurred. If, as existing law does provide, a lesser prejudice test defines the right, subject to posttrial harmless error review, then an appellate or habeas court would conclude that a constitutional violation had occurred but would still uphold the conviction on the ground that the violation was harmless. Thus, for rights such as the right to effective assistance of counsel, which is almost invariably raised for the first time on appeal or in habeas corpus, the choice between a strict outcome-oriented prejudice test and a more relaxed test subject to the Chapman harmless error rule principally affects only the language a court uses in stating its conclusion to uphold or invalidate the conviction, not the conclusion itself.

157. Note two differences. First, under existing law, the likelihood of an impact on the outcome needed to satisfy the outcome-oriented prejudice test is greater than that needed to demonstrate under Chapman that error is harmful. The outcome-oriented prejudice test adopted by the Supreme Court requires a "reasonable probability" that the evidence in question may affect the outcome. Bagley, 473 U.S. at 682 (emphasis added). The Chapman harmless error rule requires only a "reasonable possibility" that the evidence in question may affect the outcome. Chapman, 386 U.S. at 24 (emphasis added). The Supreme Court has made it clear that the Chapman test is more favorable to a defendant than the "reasonable probability of a different outcome" prejudice test. Bagley, 473 U.S. at $680-81$.

Second, the outcome-oriented prejudice test and the Chapman rule impose the burden of persuasion on different parties. The defendant bears the burden of convincing a court that the outcome-oriented prejudice test is satisfied, Strickland v. Washington, 466 U.S. 668, 693 (1984), while the prosecution bears the burden of demonstrating the

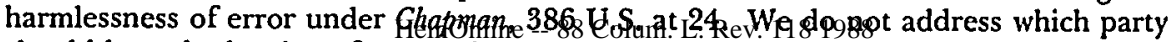
should bear the burden of persuasion. 
In contrast, the choice has great significance for rights asserted at trial. The lesser prejudice test permits a defendant to obtain and present a greater range of evidence, by cross-examining prosecution witnesses for bias, for instance, even though the witness adds nothing of significance to the prosecution's case, the cross-examination would not add anything to other evidence of bias already before the jury, or the evidence of guilt is so overwhelming that a rational jury would be compelled to convict. Under an outcome-oriented prejudice test, however, a defendant would be denied any right to cross-examine the government witness.

The Supreme Court has used both approaches in defining the rights to present evidence. It has held that a defendant must satisfy a prejudice test phrased in terms of likely impact on the outcome to establish a violation of his constitutional rights to effective assistance of counsel, 158 to obtain exculpatory evidence in the government's posses$\operatorname{sion}^{159}$ and to interview alien witnesses whom the government has deported.160 In each of these situations, a defendant can establish constitutional error only by showing that compliance with the asserted right would create a "reasonable probability" of an acquittal or conviction on a lesser charge.

In contrast, the Court recently held that a defendant ordinarily need not show outcome-influencing prejudice to establish violations of the rights to cross-examine government witnesses for bias ${ }^{161}$ and to elicit favorable testimony from his own witnesses. ${ }^{162}$ For these rights, a showing of a possible or likely impact on the outcome becomes relevant only after the trial when an appellate or a habeas court applies the Chapman test to decide whether the constitutional error was harmful.

Yet the Court has not articulated a convincing rationale for distinguishing when courts ought to define a right to obtain or present evidence at trial in terms of a strict outcome-oriented prejudice test from when they ought to use a lesser prejudice test, subject to post-trial harmless error review. The Court has attempted to justify using a lesser prejudice test in only one case, Delaware $v$. Van Arsdall. ${ }^{163}$ The Court reasoned that the language of the confrontation clause ${ }^{164}$ fore-

158. See Strickland, 466 U.S. at 694.

159. See Bagley, 473 U.S. at 682 ; United States v. Agurs, 427 U.S. 97, 112 (1976); cf. California v. Trombetta, 467 U.S. 479, 488 (1984) (government has no constitutional duty to preserve suspected drnnk driver's breath sample unless the evidence "might be expected to play a significant role in the suspect's defense').

160. See United States v. Valenzuela-Bernal, 458 U.S. 858, 872-74 (1982); cf. United States v. MacDonald, 435 U.S. 850, 858-59 (1978) (using outcome-oriented prejudice requirement to define right to a speedy trial).

161. See Delaware v. Van Arsdall, 106 S. Ct. 1431, 1436 (1986).

162. See Crane v. Kentucky, 106 S. Ct. 2142, 2146-47 (1986).

163. 106 S. Ct. 1431 (1986).

164. "In all criminal prosecutions, the accused shall enjoy the right . . . to be confronted with the witnesses against him ... G.S. Const. amend. $v 1$. 
closes use of an impact-on-the-outcome prejudice test to define a defendant's right to cross-examine a government witness for bias. The Court stated: " $[T]$ he focus of the Confrontation Clause is on individual witnesses. Accordingly, the focus of the prejudice inquiry in determining whether the confrontation right has been violated must be on the particular witness, not on the outcome of the entire trial."165 Although only enunciated in a single case, the Court's reasoning is of general applicability. It implies that courts should eschew reliance on a strict outcome-oriented prejudice test whenever a defendant asserts a right based on the confrontation clause or the compulsory process clause, ${ }^{166}$ which also speaks of "witnesses." In fact, the Court's reasoning is inconsistent with its earlier decision in United States v. Valenzuela-Bermal, ${ }^{167}$ which held that when the government has deported a potential defense witness, a defendant must show that that witness' testimony may have affected the outcome in order to establish a compulsory process violation.

The broad rationale the Court has articulated in support of applying a prejudice test that does not focus on the outcome reads too much into the language of the confrontation and compulsory process clauses. It is true, as the Court has observed, that those clauses speak of witnesses "against" a defendant and "in his favor." The meaning of this language, though, is not self-evident. The Court's interpretation seems to require courts to focus solely on the particular witness in question without regard to his overall role in the case. But it does not strain the constitutional text to conclude that whether a witness is adverse or favorable must be determined with reference to all of the evidence adduced at trial. In addition, the language does not answer whether a witness' "favorableness" or "adverseness" should be determined under a simple relevance or an impact-on-the-outcome test. That is, it provides no basis for deciding whether a "favorable" witness is one whose testimony is merely relevant to the defense, even though it may be entirely cumulative, or is one whose testimony may realistically play a role in influencing a reasonable jury to return a more favorable verdict.

Lacking clear guidance from the constitutional text, courts must necessarily consult the purposes of constitutional rights. When it has defined the existence of a right to obtain and present evidence in terms of a strict outcome-oriented prejudice test, the Court has in fact appealed to constitutional purpose. Rather than focusing on constitutional language, these decisions construe a defendant's rights in light of and as limited by their perceived purpose of ensuring the reliability of guilty verdicts. ${ }^{168}$ The Court has reasoned that because the concern

165. Van Arsdall, 106 S. Ct. at 1436.

166. "In all criminal prosecutions, the accused shall enjoy the right . . to have compulsory process for obtaining witnesses in his favor . ..." U.S. Const. amend. V1. 
for accurate adjudication of guilt is not implicated when recognition of an asserted right would have no effect on the outcome, rights having truth-furthering purposes simply do not exist in such a situation. This logic asserts that rights should extend no further than strictly necessary to achieve their underlying purposes.

The rationale that the Court has advanced in support of adopting a strict outcome-oriented prejudice test at trial, though properly concerned with constitutional purposes, overlooks strong reasons for defining rights more broadly than their truth-furthering purposes strictly require. An impact-on-the-outcome prejudice test is difficult for courts to apply before and during trial. ${ }^{169}$ Because the nature, strengths and weaknesses of both the defense and the prosecution will not yet have been fully exposed, there is a considerable risk that such a requirement will be misapplied, and a valid right erroneously denied. Even though an appellate court can rectify the error, ${ }^{170}$ the conviction must be overturned and a new trial held. Reversal, of course, impairs the finality of the trial outcome and retrial requires an added expenditure of judicial resources. Dispensing with the impact-on-the-outcome prejudice test in favor of a more relaxed prejudice standard would reduce the risk of error and better protect the finality of the trial result.

Such an argument-that courts, to protect finality interests, should adopt a prejudice test that does not focus on the outcome-may strike some as inconsistent with the argument that the Court has implicitly given too much weight to finality interests in its harmless error jurisprndence. ${ }^{171}$ The inconsistency, however, is only apparent. When confronted with a choice between safeguarding the finality of the trial's outcome and vindicating the purposes of a given constitutional right, the Court must choose the latter, at least on direct appeal. Yet this is not the choice a trial court must make when it decides to define a right

The Sixth Amendment recognizes the right to the assistance of counsel because it envisions counsel's playing a role that is critical to the ability of the adversarial system to produce just results. An accused is entitled to be assisted by an attorney, whether retained or appointed, who plays the role necessary to ensure that the trial is fair.

... In giving meaning to the requirement [of effective assistance of counsel], however, we must take its purpose-to ensure a fair trial-as the gnide. The benchmark for judging any claim of ineffectiveness must be whether counsel's conduct so undermined the proper functioning of the adversarial process that the trial cannot be relied on as having produced a just result.

Id. at 685-86 (emphasis added).

169. In Valenzuela-Bernal, the Court recognized the difficulty of applying an impacton-the-outcome prejudice test before and during trial, stating: "Because determinations of materiality are often best made in light of all of the evidence adduced at trial, judges may wish to defer ruling on motions until after the presentation of the evidence." 458 U.S. at 874.

170. But see supra note 107 .

171. See supra notes 51-52 and accompanying text. 
to obtain or present evidence in terms of a strict outcome-oriented or some lesser prejudice test. Defining such a right more broadly than its truth-furthering purpose strictly requires will not sacrifice the purpose of a constitutional right. Indeed, in many contexts, the interests upon which such a broad definition will impinge are not very strong. In Van Arsdall, for instance, where the defendant sought to cross-examine a government witness concerning favorable treatment he had received from the government, the only interest in precluding this line of crossexamination involved saving the court's time. Interests no stronger than this are outweighed by the increased risk of error and concomitant loss of finality associated with a strict outcome-oriented prejudice test. There is no inconsistency in saying that finality must give way to vindicating the purposes of a constitutional right but prevails over a concern for saving a trial court's time.

Of course, it must be added that the increased risk of error and the loss of finality associated with a strict outcome-oriented prejudice test does not mean that such a test is always inappropriate. In some contexts, a defendant's right to obtain or present evidence conflicts with strong governmental interests. A defendant may, for instance, seek to introduce national security secrets into evidence as part of his defense. ${ }^{172}$ The broader the scope of a defendant's right to present evidence at trial, the more it will intrude upon important national security interests. Because these interests should override the increased risk of error and loss of finality associated with an outcome-oriented prejudice test, it makes sense to use such a test to define the scope of a defendant's right to adduce national security secrets in support of his defense. ${ }^{173}$ A prejudice test focusing on the outcome preserves the essential truth-furthering purpose of a defendant's right to present a defense while minimizing harm to countervailing governmental interests.

As this discussion demonstrates, the reasons given by the Court for selecting the specific prejudice test courts should use at trial to define a defendant's rights to obtain and present evidence are simplistic. One rationale fails to see important ambiguities in the constitutional text; the other is too categorical in its use of constitutional purpose. In contrast, the approach that we propose would balance the loss of finality resulting from the difficulty of applying an outcome-oriented prejudice test at trial against the harm a more broadly defined right would cause to competing governmental interests.

The approach presented here explains the Court's decisions better than does either rationale the Court has advanced. Both rationales imply, contrary to the Court's actual decisions, that courts should use one

172. See, e.g., United States v. Smith, 592 F. Supp. 424 (E.D. Va. 1984), rev'd in part and vacated in part, 780 F.2d 1102 (4th Cir. 1985) (en banc).

173. See Stacy, The Constitution in Conflict: Espionage Prosecutions, the Right to Present a Defense, and the State Secrets Privilege, 58 U. Colo. L. Rev. 177 (1987). 
kind of prejudice test to define all aspects of the right to obtain and present evidence at trial. Under our approach, the nature of the appropriate prejudice test varies depending on the strength of the interest in limiting a defendant's right to obtain and present evidence.

Consider a defendant's compulsory process and confrontation rights to elicit testimony from witnesses at trial. The Court has properly rejected use of an outcome-oriented prejudice test to define a defendant's right to present evidence in cases where the admission of the evidence would not infringe upon any substantial governmental interests. In Van Arsdall, for instance, the Court refused to require the defendant to show outcome-oriented prejudice when the trial court had, simply to save time, precluded him from cross-examining a government witness about a source of potential bias. Similarly, in Crane $v$. Kentucky, ${ }^{174}$ the Court held that the trial court had deprived the defendant of either his confrontation or compulsory process rights to present evidence by excluding testimony casting doubt on the reliability of his confession. The Court noted that neither the lower courts nor the prosecution had "advanced any rational justification for the wholesale exclusion of this body of potentially exculpatory evidence."175 In declining to discuss whether the exclusion of this evidence may have affected the outcome and in remanding the case for application of the Chapman harmless error rule, the Court implicitly refused to require a defendant to meet an outcome-oriented prejudice test at trial to establish a compulsory process or confrontation right to present such evidence. The Court in Crane and Van Arsdall was correct in refusing to require the defendants to satisfy an outcome-oriented prejudice test at trial. When the interest favoring exclusion of the evidence is no more substantial than that of saving the trial court's time, it is outweighed by the increased risk of error and loss of finality associated with an outcome-oriented prejudice test.

Unlike the broad rationale upon which the Court relied in Van Arsdall, however, the approach proposed here does not imply categorical rejection of an outcome-oriented prejudice test in all instances when a defendant claims a confrontation or compulsory process right to elicit testimony from a witness. Our approach can thus explain the Court's decision in United States $v$. Valenzuela-Bernal. ${ }^{176}$ In that case, the government had deported some of the aliens whom the defendant had allegedly transported illegally into this country, thereby preventing the defense from calling them as witnesses. The Court held that the defendant was required to show that the witnesses' testimony could reasonably have affected the outcome to establish a violation of his compulsory process rights. Under the approach proposed here, the Court correctly adopted an outcome-oriented prejudice test. Although

174. 106 S. Ct. 2142 (1986).

175. Id. at 2147.

176. 458 U.S. 858 (I982). 
such a test sacrifices finality to some degree, that sacrifice is outweighed by the executive branch's article II obligation to enforce immigration laws. ${ }^{177}$

Our approach also yields solutions to issues involving confrontation and compulsory process situations that the Court has yet to confront. Imagine, for instance, that a defendant seeks to elicit testimony in derogation of an evidentiary privilege such as the attorney-client or self-incrimination privilege. The Court has not settled the issue of whether and to what extent a defendant's right to present a defense prevails over evidentiary privileges or rules. ${ }^{178}$ If the right to present a defense does prevail over a nonarbitrary evidentiary privilege, the Court should require a defendant to show that the evidence may reasonably affect the outcome as a prerequisite to overcoming the privilege. The Court also has not specified the showing that a defendant must make to establish a compulsory process right to have the court subpoena a witness. But when the only reason for refusing to issue a subpoena relates to time and expense, a defendant should not need to show that the prospective witness' testimony might reasonably affect the outcome. Instead, he should be required to show only that the witness' testimony is relevant to his defense.

In addition to yielding answers to unresolved issues, the approach we propose furnishes a basis for criticizing other Supreme Court decisions. It suggests that the Court has erred in defining the parameters of the prosecution's Brady obligation to disclose exculpatory information to the defense. ${ }^{179}$ This obligation, the Court has held, arises only

177. Id. at $872-73$.

178. See Rock v. Arkansas, I07 S. Ct. 2704, 2711 n.11 (1987); Pennsylvania v. Ritchie, 107 S. Ct. 989, 1003 (1987); Davis v. Alaska, 415 U.S. 308, 319 (1974); Washington v. Texas, 388 U.S. 14, 21-23 \& n.21 (1967); Roviaro v. United States, 353 U.S. 53, 60-62 (1957).

Lower courts have not resolved the collision between a defendant's right to present a defense and evidentiary privileges in an entirely uniform fashion. Compare Valdez $\mathrm{v}$. Winans, 738 F.2d 1087, 1090 (10th Cir. 1984) (attorney-client privilege prevails over defendant's right to present a defense) with State v. Leecy, 294 N.W.2d 280, 283 (Minn. 1980) (marital privilege must yield to defendant's right to present a defense). Courts have been virtually unanimous, however, in holding that, at least in the absence of prosecutorial misconduct, a defendant has no constitutional right to have a court or prosecutor grant immunity to a potential defense witness who invokes his fifth amendment privilege against self-incrimination. See, e.g., United States v. Brutzman, 731 F.2d 1449, 1451-52 (9th Cir. 1984); see also Stacy, supra note 173, at 224-26 \& nn.186-87 (citing authority).

For general discussions of the collision between evidentiary privileges and a defendant's right to present a defense, see Hill, Testimonial Privilege and Fair Trial, 80 Colum. L. Rev. 1173 (1980); Westen, Reflections on Alfred Hill's "Testimonial Privilege and Fair Trial," 14 U. Mich. J.L. Ref. 371 (1981); Westen, Compulsory Process 1, supra note 120, at 159-77; Note, Defendant $v$. Witness: Measuring Confrontation and Compulsory Process Rights Against Statutory Communications Privileges, 30 Stan. L. Rev. 935 (1978).

179. See Brady v. Maryland, 373 U.S. 83, 87 (1963). 
when the information in question creates a "reasonable probability" of a different outcome. ${ }^{180}$ This outcome-oriented prejudice test is generally applied before trial by the prosecutor, who will often be unaware of the nature of the planned defense. Even when the prosecutor is aware of the nature of the defense, his partisan role in the proceedings makes him particularly likely to overvalue the strengths of his case and undervalue the chance of a successful defense. In combination, these factors result in an extraordinarily high risk that an outcome-influencing standard will be misapplied, even by a prosecutor acting in good faith. ${ }^{181}$

Given this greater risk of error, a correspondingly stronger governmental interest is needed to justify use of an outcome-oriented prejudice test. It is true that the prosecutor's duty to disclose exculpatory information runs counter to the premises of a pure adversary system. ${ }^{182}$ But the interest in preserving this structure in the criminal context must be weighed in light of the prosecutor's obligation to do justice and his greater access to investigatory resources. In addition, the Court has exaggerated the impact that defining the prosecution's duty of disclosure more broadly would have on the adversary system. The Court has expressed concern that using a lesser prejudice standard would "impos[e] upon the prosecutor a constitutional duty to deliver his entire file to defense counsel." 183 Realistically, though, a standard of prejudice requiring merely that the government reveal affirmative evidence of innocence or evidence tending to impeach government witnesses would have no such effect. A prosecutor's files do not consist mostly, much less entirely, of evidence favorable to the defense. The strength of the government's general interest in nondisclosure should be deemed insufficient to outweigh the risk that an outcome-oriented prejudice test will be erroneously applied, thereby necessitating reversal. It is a mistake, then, to use such a standard in defining the prosecution's Brady obligations. ${ }^{184}$

In sum, the Court has not articulated a persuasive rationale courts can use in deciding whether to define a defendant's various rights to

180. United States v. Bagley, 473 U.S. 667, 682 (1985).

181. 1d. at 696-703 (Marshall, J.; dissenting); id. at 714 (Stevens, J., dissenting).

182. Babcock, Fair Play: Evidence Favorable to an Accused and Effective Assistance of Counsel, 34 Stan. L. Rev. 1133, 1134 (1982).

183. Bagley, 473 U.S. at 880 .

184. Use of a more relaxed standard of prejudice to define the prosecution's Brady obligations does not eliminate the need for our proposal that courts use a sanction harsher than the Chapman rule to deter Brady violations. See supra notes $103-08$ and accompanying text. The proposal here is aimed at a different problem: the risk that a prosecutor will in good faith misapply an outcome-oriented prejudice requirement-a risk that seems unacceptably great because, when Brady issues arise (before and during trial), prosecutors lack information about the nature and strength of the defense and because the prosecutor's judgment is skewed by his partisan role. The proposal in Part 11 is, in contrast, designed to deter intentional or negligent Brady violations. Such a sanction is warranted because it is reasonable to presume that a significant number of such violations will not be detected by defense counsel or the court. 
obtain or present evidence in terms of an outcome-oriented prejudice test at trial, or a lesser standard, subject to post-trial harmless error review. The two rationales the Court has advanced, one based on the constitutional text and the other appealing to constitutional purposes, are too simplistic and categorical. Instead, courts should be required to balance the loss of finality resulting from the increased risk that an outcome-oriented prejudice test will be misapplied at trial against the strength of any governmental interest a more lenient prejudice test might impair.

\section{The Scope of Review Under Outcome-Influencing Tests}

Once it is decided that an impact-on-the-outcome standard is appropriate, either as a harmless error rule or as a prejudice test defining a right at trial, it becomes necessary to consider the scope of review that the standard entails. At present, the proper scope of review is the subject of considerable uncertainty, confusion and dispute. ${ }^{185}$ In applying the Chapman test, for instance, some courts have focused on the essentially empirical question of whether the jury that actually convicted the defendant would have done so had no constitutional error occurred. ${ }^{186}$ Others have looked to how a hypothetical average jury would have decided the case in the absence of constitutional error. ${ }^{187}$

185. The Florida Supreme Court recently spoke of the confusion many courts experience in applying the Chapman rule:

In his perceptive essay, The Riddle of Harmless Error, former Chief Justice Traynor addressed various common errors which, historically, appellate courts fall into when applying harmless error analysis. The worst is to abdicate judicial responsibility by falling into one of the extremes of all too easy affirmance or all too easy reversal. Neither course is acceptable. The test must be conscientiously applied and the reasoning of the court set forth for the guidance of all concerned and for the benefit of further appellate review. The test is not a sufficiency-of-the-evidence, a correct result, a not clearly wrong, a substantial evidence, a more probable than not, a clear and convincing, or even an overwhelming evidence test. Harmless error is not a device for the appellate court to substitute itself for the trier-of-fact by simply weighing the evidence.

State v. DiGuilio, 491 So. 2d 1129, 1 I39 (Fla. 1986). Ironically, the Florida Supreme Court has itself often misapprehended the nature of harmless error analysis, employing on various occasions some of the very tests that it criticizes in DiGuilio. See, e.g., Bundy v. State, 471 So. 2d 9, 19 (Fla. I985) ("After a thorough examination of the record before us in this case, we feel that sufficient evidence does exist, absent the tainted testimony, upon which the jury could have based its conviction of [defendant]."), cert. denied, 107 S. Ct. 295 (1986); Jones v. State, 449 So. 2d 253, 263 (Fla.) (error harmless because "other evidence supporting [defendant's] convictions is overwhelming"), cert. denied, 469 U.S. 893 (I984).

Other courts and commentators have also noted the confusion surrounding the meaning of harmless constitutional error. See supra note 13.

186. See infra notes $195-96$ and accompanying text.

187. See, e.g., Schneble v. Florida, 405 U.S. 427,432 (1972) ("we conclude that the 'minds of an average jury' would not have found the State's case significantly less persuasive" had the error not occurred) (quoting Harrington v. California, 395 U.S. 250, 254 (1969)); Harrington, 395 U.S. at 254 ("Our judgment [as to whether constitutional 
The scope of review for both the harmless error and the outcomeoriented prejudice tests must respect a criminal defendant's constitutional right to a jury trial. While such review is not inevitably incompatible with that right, ${ }^{188}$ prevailing conceptions of outcome-oriented standards violate the sixth amendment right to a jury trial by inviting judges to make probabilistic judgments of a defendant's guilt based on their own views of the weight and credibility of evidence. The inquiry proposed here preserves the jury's proper role in the criminal process. This inquiry, which borrows techniques that courts use in ruling on civil motions for summary judgment, directed verdict and judgment n.o.v., asks whether the error (in the case of harmless error review) may have affected, or the claimed right (in the case of a standard of prejudice) may affect, a reasonable jury drawing all inferences in a defendant's favor.

\section{A. Impact-on-the-Outcome Rules and the Jury's Role}

The role of a criminal jury unquestionably includes the prerogative to resolve reasonable disputes concerning the weight and credibility of the evidence on issues relating to a defendant's guilt or innocence. ${ }^{189}$ Rules requiring judges to assess the impact of error on the outcome create a danger of sanctioning judicial intrusion upon a jury's role. Ideally, a reviewing court assessing the impact of constitutional error would simply determine how the jury would have decided an issue in the absence of constitutional error. Unfortunately, courts cannot know how a jury would have resolved questions of fact over which reasonable persons can disagree. The Supreme Court has therefore formulated the impact-on-the-outcome standards in terms of "reasonable probability" and "reasonable doubt." As a result of these ambiguous directions, however, lower courts seeking to apply these standards have often usurped the jury's constitutional prerogatives.

1. Displacing the Jury. - A few appellate courts have held that constitutional error may be harmless if the jury reached the "correct result."190 This approach necessarily requires the appellate court to imagine the result it would have reached had it been the trier of fact, thereby substituting its own judgment for that of the jury. By basing its

error is harmless] must be based on our own reading of the record and on what seems to us to have been the probable impact of [the error] on the minds of the average jury.").

188. See infra notes $220-35$ and accompanying text.

189. See, e.g., United States v. Bailey, 444 U.S. 394, 414-15 (1980) ("It is for [jurors], generally, and not for appellate courts, to say that a particular witness spoke the truth or fabricated a cock-and-bull story."); Jackson v. Denno, 378 U.S. 368, 386 n.13 (1964) (questions concerning credibility of evidence are for the jury); United States v. Toomey, 764 F.2d 678, 68I (9th Cir. 1985) ("It is the jury's duty to weigh the evidence and determine what version of the facts to believe."), cert. denied, 106 S. Ct. 828 (1986).

190. R. Traynor, supra note 11 , at $18-22$, and cases cited therein; see State v. Watkins, 219 Kan. 81, 94, 547 P.2d 810, 822 (1976); Burks v. State, 594 P.2d 771, 774 (Okla. Crim. App. 1979). 
decision to vacate or uphold the conviction on its own evaluation of the weight and credibility of the evidence, these appellate courts usurp the jury's role. ${ }^{191}$

The Chapman rule, by directing courts' attention to the impact of error on juries, obviously differs from the "correct result" approach. Nonetheless, certain conceptions of the Chapman harmless error rule and the "reasonable probability" prejudice test entail similar, if less blatant, interference with a jury's prerogatives. Some courts have come very close to treating the Chapman rule as embracing a sufficiency of the evidence inquiry, ${ }^{192}$ even though the Supreme Court has stated unequivocably that harmless error analysis is not a sufficiency of the evidence test. ${ }^{193}$ Under this understanding of harmless error, a conviction must be upheld if a rational jury drawing all inferences in the government's favor at a trial free from constitutional error could have found the defendant guilty beyond a reasonable doubt. ${ }^{194}$ This approach obviously does not adequately protect a defendant's right to a jury trial, for it presupposes that the jury did or will resolve all evidentiary conflicts in the prosecution's favor.

Other courts do not make the gross error of construing the Chapman rule as a sufficiency of the evidence test and ask the empirical question of whether the constitutional error affected the jury that actually convicted the defendant. ${ }^{195}$ To these courts, harmless beyond a

191. R. Traynor, supra note 11, at 20-21; Saltzburg, supra note 11, at 1020; Teitelbaum, supra note 13 , at 1187 .

192. See, e.g., United States v. Schmitt, 794 F.2d 555, 560 (10th Cir. 1986) ("We are satisfied beyond a reasonable doubt that the quantum of other evidence of appellant's ... guilt supports the jury's verdict ...."); United States v. Koopmans, 757 F.2d 901,905 (7th Cir. 1985) (finding error harmless "because there was more than sufficient evidence to support the verdict"); Guizar v. Estelle, 640 F. Supp. 1146, 1152 (S.D. Cal. 1986) ("It is the opinion of this court that the evidence presented below establishes beyond a reasonable doubt that the petitioner acted with the [requisite] intent . . . and thus, the error in the [intent] instruction is harmless.").

Some courts commingle a sufficiency of the evidence approach with one or more other tests. See, e.g., United States v. Pavelski, 789 F.2d 485, 490 (7th Cir.) (combining "average jury" and overwhelming evidence tests with sufficiency of the evidence test), cert. denied, 107 S. Ct. 322 (1986).

193. See, e.g., Bundy v. Florida, 107 S. Ct. 295, 297 (1986) (Brennan, J., dissenting from denial of certiorari) (noting that Chapman harmless error analysis should not be confused with review for sufficiency of the evidence); Darden v. Wainwright, $106 \mathrm{~S}$. Ct. 2464, 2480 (1986) (Blackmun, J., dissenting); Fahy v. Connecticut, 375 U.S. 85, 86-87 (1963) ("We are not concerned here with whether there was sufficient evidence on which the petitioner could have been convicted without the evidence complained of. The question is whether there is a reasonable possibility that the evidence complained of might have contributed to the conviction.").

194. See Jackson v. Virginia, 443 U.S. 307, 319 (1979) (Evidence is sufficient to support conviction if "after viewing the evidence in the light most favorable to the prosecution, any rational trier of fact could have found the essential elements of the crime beyond a reasonable doubt.").

195. Language in several Supreme Court decisions suggests that harmless error analysis entails an empirical evaluation of the likely infiyence the error had on the jury's 
reasonable doubt means that the court is convinced beyond a reasonable doubt that the error did not actually affect the jury's decision to convict. Although an error could have influenced a hypothetical reasonable jury applying the reasonable doubt standard and drawing all reasonable inferences in the defendant's favor, a court may declare the error harmless so long as it is convinced that the error did not affect the jury that actually convicted the defendant. This approach would be unobjectionable if courts had information that would allow them to draw reliable inferences about how a particular jury resolved disputes about the weight and credibility of the evidence. Not surprisingly, though, empirical data show that courts do a remarkably poor job of evaluating the importance jurors attach to specific issues and evidence. ${ }^{196} \mathrm{Be}-$

decision to convict. See, e.g., Rose v. Clark, 106 S. Ct. 3101,3108 n.11 (1986) (the proper analysis asks whether the error "in practice clearly had no effect on the outcome"); Darden v. Wainwright, 106 S. Ct. 2464, 2472-73 (1986) (heavy weight of evidence "reduced the likelihood that the jury's decision was influenced by [error]"); United States v. Hasting, 461 U.S. 499, 510-11 (1983) ("The question a reviewing court must ask is this: absent [constitutional error] is it clear beyond a reasonable doubt that the jury would have returned a verdict of guilty?"); Milton v. Wainwright, 407 U.S. 371, 377 (1972) ("Our review of the record ... leaves us with no reasonable doubt that the jury at petitioner's 1958 trial would have reached the same verdict" had the error not occurred.).

Several lower courts have since construed these precedents to require such a pragmatic assessment of the impact of error on the actual convicting jury. See, e.g., Dix v. Kemp, 804 F.2d 618, 622 (11th Cir. 1986) ("We cannot say beyond a reasonable doubt that the jury did not rely on the faulty presumption in reaching its verdict."); Myrick v. Maschner, 799 F.2d 642, 645-46 (10th Cir. 1986) (interpreting Rose to require an assessment of whether error actually affected the jury verdict and concluding that burdenshifting instruction "did not have a practical effect on the determination of the jury"); Passman v. Blackburn, 797 F.2d 1335, 1350 (5th Cir. 1986) (Despite the constitutional error, "[a]fter an examination of the entire trial record ... it is clear beyond a reasonable doubt that the jury would have returned a verdict of guilty."), cert. denied, $107 \mathrm{~S}$. Ct. 1609 (1987); United States v. Sutton, 794 F.2d 1415, 1429 (9th Cir. 1986) (error was harmless because it "had an insignificant impact, if any, upon the minds of the jurors who found [defendant] guilty").

In Pope v. Illinois, 107 S. Ct. 1918 (1987), however, the Court expressly disavowed the notion that Chapman requires or permits a reviewing court to "retrace the jury's deliberative processes." Id. at 1922 n.6.

196. In their comprehensive empirical study examining jury behavior as it relates to the erroneous admission or exclusion of evidence, Professors Teitelbaum, SuttonBarbere and Johnson found strong evidence demonstrating that appellate judges do not and cannot accurately gauge the impact that particular evidence had or would have had on the particular jury that convicted the defendant. See Teitelbaum, supra note 13, at 1197.

Other commentators, too, have observed that reviewing courts are not in a position to assess the impact of particular evidence on particular juries. See, e.g., R. Traynor, supra note 11, at 20-21; 1 Weinstein's Evidence, supra note 13, 8103 [06], at 103-80; Sobieski, The Theoretical Foundations of the Proposed Tennessee Rules of Appellate Procedure, 45 Tenn. L. Rev. 161, 258-59 (I978); see also Rose v. Clark, 106 S. Ct. 3101 , 3115 (1986) (Blackmun, J., dissenting) ("[a] reviewing court simply cannot determine whether this jury in fact relied on" a constitutionally impermissible burden-shifting instruction). 
cause the jury's deliberations are secret, courts have no way to determine whether the error actually influenced the jury except to rely upon their own perceptions of the weight and credibility of the evidence. This empirical conception of Chapman, then, comes close to being the functional equivalent of the "correct result" test.

Still other courts hold constitutional error harmless under Chapman if the evidence of guilt is "overwhelming." 197 Of course, the "evidence" under consideration must be adjusted for the error by including unconstitutionally excluded evidence and excluding unconstitutionally admitted evidence. So conceived, the overwhelming evidence test would be consistent with a defendant's right to a jury trial if "overwhelming" evidence meant evidence that would compel a rational jury resolving all reasonable evidentiary conflicts in the defendant's favor to convict as a matter of law. But in practice most courts employ a less restrictive definition. Even when a reasonable jury viewing the evidence most favorably to the defendant would not be compelled to convict, these courts describe the evidence of guilt as overwhelming as long as they are convinced that a hypothetical reasonable or average jury is highly likely to convict at an error-free trial. ${ }^{198}$ To determine

197. Several Supreme Court opinions suggest an "overwhelming evidence" test of harmless constitutional error without explaining the meaning of "overwhelming." See, e.g., Bundy v. Florida, 107 S. Ct. 295, 297 (1986) (Marshall, J., dissenting from denial of certiorari); Rose, $106 \mathrm{~S}$. Ct. at 3110 (Burger, C.J., concurring in the judgment); United States v. Hasting, 461 U.S. 499, 512 (1983); Milton v. Wainwright, 407 U.S. 371,377 (1972); Schneble v. Florida, 405 U.S. 427, 431 (1972). Perhaps due to the Court's persistent use of the concept of "overwhelming evidence" in connection with its discussions of the Chapman rule, "[t]here has been a marked tendency in the circuit courts to find constitutional error harmless when they find other evidence of guilt overwhelming, without specifically analyzing the prejudicial effect of the error itself." 1 Weinstein's Evidence, supra note 13, § 103[08], at 103-97 to -98 (1986 \& Supp. 1987) (footnote omitted); see, e.g., United States v. Disla, 805 F.2d 1340, 1347 (9th Cir. 1986) (finding error harmless even though some evidence supported defendant's claim of innocence because "the government presented overwhelming evidence"); Flittie v. Solem, 775 F.2d 933, 944 (8th Cir. 1985) ("It is unlikely that [the error] had a major impact on the jury in determining whether these witnesses were believable. The whole record shows overwhelming independent evidence to support the conviction."), cert. denied, 475 U.S. 1025 (1986). Yet in Chapman itself, the Court suggested that harmless error analysis should not be cast as an overwhelming evidence test. Chapman v. California, 386 U.S. 18,23 (I967) (noting state court's "overemphasis" on its own view that the evidence of guilt was "overwhelming").

Some judges and many commentators have criticized the widespread characterization of Chapman harmless error analysis as an overwhelming evidence test, though not necessarily for the reasons given here. See, e.g., Harryman v. Estelle, 616 F.2d 870, 884-87 (5th Cir.) (Clark, J., dissenting), cert. denied, 449 U.S. 860 (1980); United States v. Hunt, 548 F.2d 268, 269-71 (9th Cir. 1977) (Sneed, J., dissenting); Field, supra note 11 , at 33; St. John's Note, supra note 13, at 559-62.

198. See, e.g., Washington v. Scully, 640 F. Supp. 1226, 1233 n.6 (S.D.N.Y. 1986) ("The mere existence of a rational basis in the evidence to justify [a finding that the defendant lacked the requisite intent] does not itself negate the circumstances that the evidence with respect to intern Q was so overWhelmme as to justify a finding that the 
how such a jury is likely to resolve reasonable evidentiary conflicts, such courts naturally cannot and do not submit the case to a statistically significant number of reasonable juries. As with the empirical approach, courts lack any objective indicia upon which to base this kind of prediction. Unless they engage in "unguided speculation," 199 then, courts applying this probabilistic conception of the overwhelming evidence test must rely on their own views concerning the weight and credibility of the evidence.

The outcome-oriented prejudice test that the Supreme Court has used to define various components of a defendant's right of access to evidence and his right to effective assistance of counsel suffers from similar shortcomings. Under this standard, a defendant must demonstrate that there is a "reasonable probability" that the asserted error will affect the outcome. ${ }^{200}$ Few courts have construed this standard to mean that a defendant need only demonstrate that a jury could reasonably acquit based in part on the evidence in question, or that counsel's unprofessional errors could reasonably have influenced a jury. Rather, courts have considered only whether there is a substantial probability that a jury would acquit based on the evidence sought or an improved performance by counsel. ${ }^{201}$ Yet, there are no objective factors upon which courts can rely in determining the probability of various reasonable resolutions of evidentiary conflicts and, hence, of various reasonable outcomes. Thus, they must depend only on their own perceptions of the strength and credibility of the evidence.

2. Preserving the Jury's Role. - The Chapman harmless error rule and the "reasonable probability" prejudice test must be redefined so that they adequately protect the jury's exclusive authority to decide the weight and credibility of evidence. The formulation proposed here borrows techniques that courts use in civil cases to decide motions for summary judgments, directed verdicts and judgments n.o.v. When ruling on a motion for summary judgment or for a directed verdict, a court is required to draw all reasonable inferences from the evidence in the nonmovant's favor; it may not grant a motion for summary judgment or directed verdict because it concludes that a reasonable jury is

Sandstrom error was harmless beyond a reasonable doubt."), cert. denied, $107 \mathrm{~S}$. Ct. 2485 (1987); cf. United States v. Hasting, 461 U.S. 499, 512 (1983) ("[i]n the face of this overwhelming evidence of guilt and the inconsistency of the scanty evidence tendered by the defendants," error was harmless).

199. Holloway v. Arkansas, 435 U.S. 475, 491 (1978).

200. See supra notes $158-60$ and accompanying text.

201. See, e.g., United States v. Massa, 804 F.2d 1020, 1025 (8th Cir. 1986); United States v. Brimberry, 803 F.2d 908, 914 (7th Cir. 1986), cert. denied, 107 S. Ct. 1977 (1987); Whitley v. Barr, 802 F.2d 1487, 1496 (4th Cir. 1986), cert. denied, 107 S. Ct. 1618 (1987); Government of V.I. v. Nicholas, 639 F. Supp. 486, 489-90 (D.V.1. 1986), aff'd, 819 F.2d 1133 (3d Cir. 1987); Government of V.I. v. Jacobs, 634 F. Supp. 933, 940 (D.V.I. 1986). 
highly likely to find in favor of the moving party. ${ }^{202}$ The court is required to deny the motion if it would be reasonable for a jury applying the relevant standard of proof ${ }^{203}$ to find in the nonmovant's favor, whatever the likelihood that it will actually do so. Similarly, a court may grant a motion for judgment n.o.v. only if it concludes that no reasonable view of the evidence would support the verdict. ${ }^{204}$

The purpose of these limitations on summary judgments, directed verdicts and judgments n.o.v. is to preserve the jury's prerogative to decide the weight and credibility of the evidence; they are a function of the seventh amendment right to a jury trial in civil cases. ${ }^{205}$ Certainly a

202.

If the defendant in a ... civil case moves for summary judgment or for a directed verdict based on the lack of proof of a material fact, the judge must ask himself not whether he thinks the evidence unmistakably favors one side or the other but whether a fair-minded jury could return a verdict for the plaintiff on the evidence presented ....

....

Credibility determinations, the weighing of the evidence, and the drawing of legitimate inferences from the facts are jury functions, not those of a judge, whether he is ruling on a motion for summary judgment or for a directed verdict. The evidence of the non-movant is to be believed, and all justifiable inferences are to be drawn in his favor.

Anderson v. Liberty Lobby, Inc., I06 S. Ct. 2505, 25I2-I3 (1986). See generally Fed. R. Civ. P. 56 advisory committee's note; Adickes v. S.H. Kress \& Co., 398 U.S. 144, 159-61 (1970) (discussing standard for granting summary judgment); Wilkerson v. McCarthy, 336 U.S. 53, 62 (1949) (discussing standard for denying directed verdict); Brady v. Southern R.R., 320 U.S. 476, 479-80 (1943) (discussing standards for directed verdict and judgment n.o.v.).

203. Anderson, $106 \mathrm{~S}$. Ct. at 25I4-I5.

204. See Fireman's Fund Ins. Co. v. Videfreeze Corp., 540 F.2d 1171, 1178 (3d Cir. 1976), cert. denied, 429 U.S. 1053 (1977); Alioto v. Cowles Communications, Inc., 519 F.2d 777, 780 (9th Cir.), cert. denied, 423 U.S. 930 (1975); O’Neil v. W.R. Grace \& Co., 410 F.2d 908, 911 (5th Cir. 1969); Harner v.John McShain, Inc., 394 F.2d 480, 482 (4th Cir. 1968); see also 5A J. Moore, Moore's Federal Practice § 50.07[2], at 50-64 (1987 \& Supp. I987) (motion for judgment n.o.v. may be granted "only when, without weighing the credibility of the evidence, there can be but one reasonable conclusion as to the proper judgment").

205. Respecting the role played by the seventh amendment in shaping summary judgment standards, the Fifth Circuit has said:

The [summary judgment] procedure, valuable as it is for striking through sham claims and defences which stand in the way of a direct approach to the truth of a case, was not intended to, it cannot deprive a litigant of, or at all encroach upon, his right to a jury trial.

Judges in giving its flexible provisions effect must do so with this essential limitation constantly in mind. To proceed to summary judgment it is not sufficient then that the judge may not credit testimony proffered on a tendered issue. It must appear that there is no substantial evidence on it, that is, either that the tendered evidence is in its nature too incredible to be accepted by reasonable minds, or that conceding its truth, it is without legal probative force.

Whitaker v. Coleman, 115 F.2d 305, 306 (5th Cir. 1940); see also, e.g., Elliot v. Elliot, 49 F.R.D. 283, 284 (S.D.N.Y. 1970) ("Since we are dealing with a procedure that operates

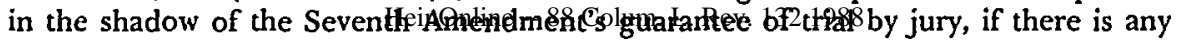


criminal defendant's sixth amendment right to a jury trial, which the Supreme Court has declared to be of special importance, ${ }^{206}$ deserves no less protection.

This conclusion has important implications. It means that a court should not uphold a conviction or conclude that a defendant has not shown the requisite level of outcome-influencing prejudice when the court's judgment is based on its own probabilistic impressions of what a jury actually did or what a hypothetical reasonable jury is likely to do. Such actions would be inconsistent with a defendant's constitutional right to a jury trial. As in the civil contexts, courts should focus solely on what it would be reasonable for a jury to do rather than the probability of various reasonable outcomes. To hold that error did not affect the outcome or that a defendant has not shown outcome-oriented prejudice, the court should have to conclude that the error did not or a claimed right would not affect the outcome as a matter of law.

In many situations, the outcome-oriented prejudice test requires a defendant to show that a particular piece of evidence may affect the outcome. ${ }^{207}$ Under the probabilistic conceptions of the standard that now exist, courts can and do deny defendants a right to obtain and present the evidence because it is of doubtful credibility or because it might, though not necessarily, be regarded as cumulative. ${ }^{208}$ Instead, courts should ask whether it would be reasonable for a jury to acquit

doubt as to the existence of a genuine issue of fact, summary judgment cannot be granted."); 10 C. Wright, A. Miller \& M. Kane, Federal Practice and Procedure § 2714, at 620-25 (1983 \& Supp. 1987).

The same concern for protecting civil litigants' seventh amendment right to a jury trial circumscribes the courts' authority to grant directed verdicts and judgments n.o.v. See Connell v. Sears, Roebuck \& Co., 722 F.2d 1542, 1546 (Fed. Cir. 1983).

206. The Court has said that the right to a jury trial in criminal cases reflects a fundamental decision about the exercise of official power-a reluctance to entrust plenary powers over the life and liberty of the citizen to one judge or to a group of judges.... The deep commitment of the Nation to the right of jury trial in serious criminal cases ... qualifies for protection under the Due Process Clause of the Fourteenth Amendment, and must therefore be respected by the States.

Duncan v. Louisiana, 391 U.S. 145, 156 (1968). In contrast, the Court has never held the seventh amendment guaranty of a jury trial in civil cases to be generally applicable to the states. See Walker v. Sauvinet, 92 U.S. 90, 92-93 (1876).

207. See supra notes $103-08$ and accompanying text.

208. See, e.g., Hopkinson v. Shillinger, 645 F. Supp. 374, 417 (D. Wyo. 1986) (no Brady violation when defendant's theories as to exculpatory nature of evidence were "highly speculative," record already contained "much of the same information," and an "abundance of evidence" of defendant's guilt existed); Smith v. State, 500 So. 2d 973, 980 (Miss. 1986) (no Brady violation when evidence of defendant's guilt was "overwhelming"); Haselhuhn v. State, 727 P.2d 280, 285 (Wyo. 1986) (evidence was not "exculpatory" when it merely corroborated what defendant himself had testified), cert. denied, 107 S. Ct. 1321 (1987); cf. Orsini v. State, 287 Ark. 456, 460, 701 S.W.2d 114, 117 (1985) (Bagley places a "heavy burden" on defendant to show that disclosure of

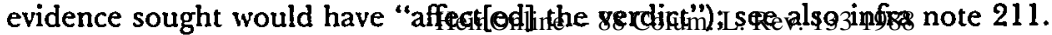


based in part on the evidence in question. ${ }^{209}$ This is an important difference. A court would deny a defendant's right to present the evidence on grounds that it is cumulative only if the evidence is cumulative as a matter of law; that is, a jury could not reasonably regard the evidence as adding anything to the other evidence a defendant will be able to present. ${ }^{210}$ Furthermore, the court would not deny a defendant a right to present evidence because it was of dubious credibility. ${ }^{211}$ It could hold that the evidence would not affect the judgment of a reasonable jury on credibility grounds only if the evidence was incredible as a matter of law; that is, no reasonable person would believe it. ${ }^{212}$ Of course, a court applying the outcome-oriented prejudice test would deny a defendant a right to present particular evidence if it concluded that, even considering the proffered evidence, the evidence of guilt was so overwhelming that a jury could not reasonably acquit. Before a court concluded that the evidence was "overwhelming," however, it would have to resolve all evidentiary conflicts in the defendant's favor (including any created by the evidence in question) and take account of the prosecution's burden to prove guilt beyond a reasonable doubt.

209. Cf. State v. Rosiere, 488 So. 2d 965, 971 (La. 1986) (Brady violation occurred where undisclosed evidence was such that "a rational trier" of fact could find based on the evidence that homicide was justified).

210. Thus, evidence should not be considered cumulative merely because it tends to establish the same facts as properly admitted evidence. See Holland v. Attorney Gen., 777 F.2d 150, 158-59 (3d Cir. 1986) (erroneously admitted evidence was not cumulative and error was therefore not harmless even though evidence was not "significantly different" from properly admitted evidence). For a court holding the erroneous admission of evidence harmless when the evidence could possibly, but not necessarily, be regarded as cumulative by a rational jury, see United States v. Disla, 805 F.2d 1340, 1347-48 (9th Cir. 1986) (evidence obtained in violation of fourth amendment was deemed cumulative and therefore admission of the evidence was held harmless, even though evidence, consisting of defendant's statement that he lived in the apartment where cocaine was found, was significantly different in kind from circumstantial evidence tending to show that defendant lived in the apartment and the circumstantial evidence was even rebutted by defendant's friends' trial testimony that he did not live there).

211. This limitation on harmless error analysis would seem obvious given the jury's constitutional prerogative to decide the credibility of witnesses. Nevertheless, despite the clear constitutional requirement that the jury rather than the judge decide credibility matters, appellate courts applying outcome-influencing standards often make judgments concerning the credibility of particular evidence or witnesses. See, e.g., United States v. Wood, 550 F.2d 435, 441 (9th Cir. 1976) (holding exclusion of a potential defense witness to be harmless error because witness would not have been credible).

212. For a general discussion of the doctrine of inherent incredibility as it applies in criminal cases, see United States v. Smith, 592 F. Supp. 424, 436-41 (E.D. Va. 1984), rev'd on other grounds, $780 \mathrm{~F} .2 \mathrm{~d} 1102$ (4th Cir. 1985) (en banc). The doctrine of inherent incredibility has been construed quite narrowly in criminal cases, permitting a court to exclude testimony only when it contradicts indisputable physical facts or laws. United States v. Lerma, 657 F.2d 786, 789 (5th Cir. 1981) (citing cases), cert. denied, 455 U.S. 921 (1982); cf. Baker v. Montgomery, 811 F.2d 557, 559-61 (11th Cir. 1987) (court concluded that defendant's "self-serving" testimony was unbelieyable as a matter of law because it was contrary to all other evidence). 
The Chapman harmless error rule typically comes into play when a trial court has unconstitutionally excluded evidence, when it has unconstitutionally admitted evidence or when an error has been committed that may have unconstitutionally skewed the jury's perception of the evidence. When evidence has been unconstitutionally excluded, a reviewing court's inquiry should be identical to that entailed by the outcome-oriented prejudice test: the error would not be considered harmless unless it would be unreasonable for a jury to acquit based in part on the evidence in question.

The inquiry is somewhat different when evidence has been unconstitutionally admitted rather than excluded. One might expect that the error should be held harmful only if it would have been reasonable for a jury to rely in part on the erroneously admitted evidence in convicting the defendant. This formulation, however, does not adequately protect the right that has been violated by admitting the improper evidence. lmagine that a court has erroneously and unconstitutionally admitted irrelevant but highly prejudicial testimony. Although it would not be reasonable for a jury to be affected by such testimony, there is a danger that the evidence may actually have influenced the verdict. Courts could attempt to address this danger by attempting to estimate the likelihood that erroneously admitted evidence actually affected the jury's decision. Yet courts have no way to do this except to rely on their own views of the weight and credibility of the other evidence of guilt. Both to preserve the jury's constitutional prerogatives and to ensure that erroneously admitted evidence did not affect the verdict, courts should vacate the conviction whenever the properly admitted evidence, wholly apart from the erroneously admitted evidence, would permit a reasonable jury to find in the defendant's favor on any dispositive issue possibly affected by the error. ${ }^{213}$

This formulation of the Chapman rule should apply not only when the constitutional error involved the erroneous admission of evidence, but also when the error may have skewed the jury's perception of the evidence. ${ }^{214}$ In this situation, too, an error may have influenced the

213. Cf. State v. Guloy, 104 Wash. 2d 412, 426, 705 P.2d 1182, 1191 (1985) (when constitutional error results in the erroneous admission of evidence, appellate court must "look[] only at the untainted evidence to determine if the untainted evidence is so overwhelming that it necessarily leads to a finding of guilt") (emphasis added), cert. denied, 106 S. Ct. 1208 (1986).

214. Suppose, for example, that the trial court erroneously instructed the jury that "a person is presumed to intend the natural consequences of his actions." When given in the context of a case in which intent is an element of the crime with which the defendant is charged, such an instruction violates the defendant's due process right to have the prosecution prove each element of the offense beyond a reasonable doubt. Sandstrom v. Montana, 442 U.S. 510 (1979). A Sandstrom error has the potential to influence the way that the jury views the evidence by creating the impression that the defendant has the burden to prove that he did not possess the requisite intent.

In Rose v. Clark, $106 \mathrm{~S}$. Ct. 3101 (1986), the Court held that Sandstrom errors could

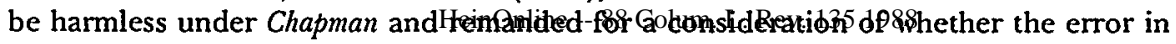


jury even though an ideally rational jury would have disregarded it. Courts should reverse unless the evidence of guilt would compel any rational jury resolving all evidentiary conflicts in the defendant's favor to find against the defendant on the issue affected by the error. ${ }^{215}$ This is the only way that appellate courts can ensure that the error did not influence the jury's decision to convict while preserving the jury's prerogative to decide the weight and credibility of the evidence.

This harmless error inquiry would undoubtedly require courts to vacate convictions more frequently than they do under current understandings of the Chapman rule. For example, when evidence has been unconstitutionally excluded, the error would be held harmless only if the evidence is cumulative, unbelievable or irrelevant as a matter of law or a jury resolving all evidentiary conflicts in a defendant's favor could not reasonably acquit. In addition, this conception of the outcome-oriented prejudice test demands recognition of broader rights, for courts may no longer decline to recognize such rights based on their own probabilistic impressions of the weight and credibility of the evidence.

Obviously, as more convictions are vacated, less protection would be afforded to interests in finality and efficiency than under received understandings of the Chapman rule and the "reasonable probability of a different outcome" prejudice test. Yet such understandings unjustifiably promote efficiency and finality at the expense of failing to vindicate constitutional rights. In situations where Chapman is designed to repair rather than deter, the prevailing conceptions of Chapman prevent the full accomplishment of this purpose. The defendant loses the opportu-

that case was harmless. The Court suggested that the appellate court should make a "practical assessment" of whether the error had an effect on the jury's decision to convict based on its own review of the record. As we have suggested, though, this pragmatic approach to harmless error review invites judges simply to assess the strength of the evidence against the defendant on the question of intent, and affirm the conviction if they find that evidence to be "overwhelming" or otherwise substantial.

The formulation proposed here is more precise, and would require a reviewing court to consider whether a rational jury could have found that the defendant lacked intent based on the evidence presented to it. As a practical matter, this means that a Sandstrom error cannot be harmless if the issue of intent is disputed and there is evidence, including the defendant's own testimony, from which a reasonable jury could entertain a reasonable doubt as to his intent. Accord State v. McKenzie, 186 Mont. 481, 535, 608 P.2d 428,459 (holding Sandstrom error harmless where "[no] reasonable juror could . . . have found [that defendant lacked requisite intent] on [uncontradicted] proof presented by the State'), cert. denied, 449 U.S. 1050 (1980).

215. In Pope v. Illinois, 107 S. Ct. 1918 (1987), the Supreme Court appeared to frame the harmless error inquiry in these terms. In Pope, the trial court had committed constitutional error in instructing the jury as to the standard governing whether allegedly obscene material has any redeeming social value. The Court declared that the error should be deemed harmless "if no rational juror" applying the proper standard could conclude that the material had redeeming social value. Id. at 1922 (emphasis added). This language implies that the error is harmless if and only if a rational jury would be compelled to find the existence of the element of the crime affected by the constitutional error. 
nity he would otherwise have had to have a jury resolve all reasonable evidentiary conflicts in his favor at a trial free from constitutional error. The evidence is instead weighed by a judge whose experience with the criminal justice system often breeds a cynicism and skepticism that contrasts sharply with the fresh and open attitude of many jurors. For the same reason, permitting judges to weigh the evidence also tends to undermine the deterrent effect of the Chapman harmless error rule. By denying the jury the prerogative to resolve all reasonable evidentiary conflicts in the defendant's favor based on a judicial determination that such a resolution is unlikely, prevailing conceptions of Chapman give prosecutors an incentive to commit constitutional error.

Finality and efficiency interests do not justify compromising the deterrent and remedial purposes of the Chapman rule. ${ }^{216}$ This conclusion finds compelling support in a comparison of the relative importance of finality and efficiency in civil and criminal proceedings. As our constitutional and statutory commitment to the availability of habeas corpus attests, ${ }^{217}$ finality and efficiency concerns carry relatively less sway in criminal cases than they do in civil cases-a product of a criminal defendant's countervailing liberty interest. ${ }^{218}$ Yet the existing conceptions of the Chapman rule, apparently in the name of finality and efficiency, anomalously accord a criminal defendant's right to a jury trial less respect than that of a civil litigant. The formulation of the Chapman rule and the related "reasonable probability of a different outcome" prejudice test suggested here would eliminate this anomaly by adapting standards civil courts use in ruling on motions for directed verdict, summary judgment and judgment n.o.v. ${ }^{219}$ th thus safeguards the jury's prerogative to weigh the evidence and places a criminal defendant's sixth amendment jury trial right on equal footing with a civil litigant's seventh amendment jury trial right.

The Supreme Court has never explicitly addressed, much less defended, the view that interests in finality and efficiency give a court authority to uphold a conviction although a jury, in a trial free of constitutional error, might rationally have acquitted. If the Court does

216. This is true at least on direct appeal. Whether it is true in habeas corpus proceeding raises questions of statutory construction concerning the intended scope of the federal habeas corpus statutes. See supra note 51 .

217. U.S. Const. art. I, § 9, cl. 2; 28 U.S.C. §§ 2241, 2254, 2255 (1982).

218. E.g., Sanders v. United States, 373 U.S. 1, 8 (1963) ("Conventional notions of finality of litigation have no place where life or liberty is at stake and infringement of constitutional rights is alleged."); cf. id. at 24 (Harlan, J., dissenting):

But the Government recognizes, as indeed it must in view of the decisions, that strict doctrines of res judicata do not apply in this field. The consequences of injustice-loss of liberty and sometimes loss of life-are far too great to permit the automatic application of an entire body of technical rules whose primary relevance lies in the area of civil litigation.

219. Although courts decide motions for directed verdict and summary judgment before judgment and before finality interests have attached, motions for judgment n.o.v. are decided after judgment. 
not remove the ambiguities in its harmless error jurisprudence that have enabled courts to assume authority to decide the weight and credibility of the evidence, it ought to explain on what theory courts have such authority.

\section{B. Impact-on-the-Outcome Rules and Jury Nullification}

Some commentators have contended that the Chapman rule necessarily violates the sixth amendment right to a jury trial because it interferes with the jury's power of nullification. ${ }^{220}$ If properly conceived, however, harmless error review can be consistent with the legitimate bases for jury nullification and the limited role existing law implicitly reserves for that power.

In criminal cases, a jury's constitutional role arguably extends beyond that of resolving reasonable conflicts in the evidence. ${ }^{221}$ The right to a jury trial, which allows juries rather than judges to decide questions of fact, is certainly intended in part to ensure that factually innocent persons are not unjustly convicted. ${ }^{222}$ It is an important corollary to the reasonable doubt standard, for it is more likely that one out of twelve jury members ${ }^{223}$ will entertain a reasonable doubt as to a

220. See, e.g., Field, supra note 11, at 33-35; Goldberg, supra note 6, at 427, 429; Mause, supra note 11 , at 531; Cornell Note, supra note 11 , at 542-43.

221. In civil cases the constitutional role of a jury is limited to the resolution of reasonable conflicts in the evidence. The seventh amendment expressly describes a civil jury's role in terms of deciding facts. The seventh amendment states, "In Suits at common law ... the right of trial by jury shall be preserved, and no fact tried by jury, shall be otherwise re-examined in any Court of the United States, than according to the rules of the common law." U.S. Const. amend. VIl (emphasis added). The language of the sixth amendment, in contrast, provides only that "[i]n all criminal prosecutions, the accused shall enjoy the right to a ... trial, by an impartial jury ...." U.S. Const. amend. VI. The Supreme Court has explicitly acknowledged that there are differences between the scope of the sixth and seventh amendment jury trial rights. See Colgrove v. Battin, 413 U.S. 149,157 (1973) (recoguizing that "the purpose of the jury trial in criminal cases [is] to prevent government oppression . . . and, in criminal and civil cases, to assure a fair and equitable resolution of factual issues") (citations omitted). See infra notes 225-26 and accompanying text.

222. Common sense suggests that the unanimous (or near unanimous) judgment of twelve (or nine, or six) jurors is less likely to result in the conviction of a factually innocent person than the opinion of a single judge. The principal advantage of jury over judge as a fact-finding device is the process of deliberation that necessarily precedes a jury verdict. See Joiner, From the Bench, in The Jury System in America 145, 146-47 (R. Simon ed. 1975). Standards of appellate review that permit reviewing courts greater latitude to set aside nonjury verdicts implicitly recognize the greater reliability of jury verdicts. See Schneider v. Pomerville, 348 Mich. 49, 54-55, 81 N.W.2d 405, 408 (1957).

Of course, not all commentators would agree that the modern jury fulfills its function of enhancing the reliability of results in judicial proceedings. See Mckeiver v. Pennsylvania, 403 U.S. 528, 551 (1971) ("Although the function of the jury is to find facts, that body is not necessarily or even probably better at the job than the conscientious judge.") (White, J., concurring); J. Frank, Law and the Modern Mind 180-81 (1930) (judge will find facts more objectively than randomly selected panel of jurors).

223. The Supreme Court has, of course, held that a criminal jury need not consist 
defendant's guilt than it is that a single judge will do so. ${ }^{224}$ Reliability of guilty verdicts, however, is not the sole aim of the sixth amendment jury trial right. ${ }^{225}$ A criminal jury has historically had the prerogative to "nullify" the law; that is, to acquit a defendant although it would be unreasonable for a jury resolving all evidentiary conflicts in his favor to do so.226 If jury nullification has a constitutional status, then perhaps commentators are correct in asserting that impact-on-the-outcome rules violate a criminal defendant's right to a jury trial. At the very least, the impact-on-the-outcome rules proposed in the preceding section would have to be reconsidered.

Existing law sends conflicting signals concerning the constitutional status of jury nullification. On the one hand, in embracing the Chapman

of twelve members, see Williams v. Florida, 399 U.S. 78 (1970), and that its verdict need not be unanimous, see Apodaca v. Oregon, 406 U.S. 404 (1972). But the Court has sought to preserve the essential functions of the historical requirements of twelve jurors and unanimity. Thus, it has held that a jury consisting of five or fewer persons is constitutionally unacceptable, see Ballew v. Georgia, 435 U.S. 223 (1978), because it creates an unacceptable risk of erroneous guilty verdicts.

224. The Supreme Court has said that the reasonable doubt standard derives not from the sixth amendment right to a jury trial, but from the due process clauses. See Apodaca, 406 U.S. at 411-12 ("We are quite sure ... that the Sixth Amendment itself has never been held to require proof beyond a reasonable doubt in criminal cases. . . The reasonable-doubt argument is rooted, in effect, in due process . . . ."). Nevertheless, these two constitutional protections are certainly intertwined. Indeed, one of the principal objections raised to the Supreme Court's decision that the sixth amendment jury trial right does not include a right to a unanimous verdict, see supra note 223, was that this holding effectively undermined the reasonable doubt requirement. See Johnson v. Louisiana, 406 U.S. 356, 399-403 (1972) (Marshall, J., dissenting).

225. "A right to jury trial is granted to criminal defendants in order to prevent oppression by the Government." Duncan v. Louisiana, 391 U.S. 145, 155 (1968); see also Singer v. United States, 380 U.S. 24, 31 (1965) ("The [jury trial right] was clearly intended to protect the accused from oppression by the Government . . ..").

226. See United States v. Dougherty, 473 F.2d 1113, 1130 (D.C. Cir. 1972); L. Levy, Origins of the Fifth Amendment 36-37 (2d ed. 1986); R. Traynor, supra note 11, at 30-33; Henderson, The Background of the Seventh Amendment, 80 Harv. L. Rev. 289, 321-22 (1966); Kadish \& Kadish, The Institutionalization of Conflict, in Law, Justice, and the Individual in Society 308, 309 (J. Tapp \& F. Levine eds. 1977); Scheflin, Jury Nullification: The Right to Say No, 45 S. Cal. L. Rev. 168, 169 (1972); Note, Jury Nullification: The Forgotten Right, 7 New Eng. L. Rev. 105, 106 (1971). Until the midseventeenth century, the criminal jury could be punished for rendering a false verdict. F. Heller, The Sixth Amendment 11-12 (1951); L. Levy, supra, at 36-37. The jury's power to grant a verdict inconsistent with the law without fear of punishment stems from Bushell's Case, Vaugh. 135, 124 Eng. Rep. 1006 (C.P. 1670), a case involving the prosecution of William Penn for unlawful assembly. Henderson, supra, at 321 .

In Sparf v. United States, 156 U.S. 51, 102 (1895), the Supreme Court held that criminal juries are not empowered to decide the law as well as the facts. Yet Sparf also acknowledged that a court may never instruct a criminal jury to find the defendant guilty no matter how overwhelming the evidence against him. Id. at 105. "The right [to nullify] was gone, but the power remained." L. Moore, The Jury 151 (1973). The notion that a criminal jury can nullify the law continues to be reflected in the well-established principles that a trial court may not direct a verdict of guilty, propound special interrogatories or set aside a verdict of not guilty in a criminal case. 
harmless error rule and the "reasonable probability of a different outcome" prejudice test, the Supreme Court has explicitly rejected the notion that a defendant has a constitutional right to an opportunity to have the jury acquit unreasonably. ${ }^{227}$ In addition, federal appellate courts have held that the Constitution does not require that the jury be informed of its prerogative to nullify the law, ${ }^{228}$ and that defendants are not entitled to introduce evidence bearing on the traditional bases for jury nullification. ${ }^{229}$ On the other hand, the Court has consistently declared that even when the evidence of guilt is absolutely compelling, courts are constitutionally prohibited from directing a verdict of guilty against a defendant. ${ }^{230}$ It is difficult, if not impossible, to justify this prohibition unless a criminal jury's traditional prerogative to nullify the law has constitutional dimensions.

This uneasy tension in the Court's precedents could be eliminated by acknowledging that jury nullification has a legitimate, though limited, constitutional status in criminal cases. Nullification has quite properly played a circumscribed role in criminal prosecutions, permitting a jury to return an unreasonable verdict only when convicting a defendant would deeply offend the community's most fundamental values. In its approved form, nullification enables a jury to show mercy for a defendant whose plight is especially sympathetic, ${ }^{231}$ to prevent prosecutors from using the criminal process for improper reasons such as squelching dissent ${ }^{232}$ and to block enforcement of antiquated or un-

227. Strickland v. Washington, 466 U.S. 668,695 (1984) (“A defendant has no entitlement to the luck of a lawless decisionmaker, even if a lawless decision cannot be reviewed.").

228. See, e.g., United States v. Anderson, 716 F.2d 446, 449-50 (7th Cir. 1983); Dougherty, 473 F.2d at 1130-37.

229. See, e.g., United States v. Gorham, 523 F.2d 1088, 1097-98 (D.C. Cir. 1975).

230. "We have stated that 'a trial judge is prohibited from entering a judgment of conviction or directing the jury to come forward with such a verdict . . . regardless of how overwhelmingly the evidence may point in that direction." " Rose v. Clark, $106 \mathrm{~S}$. Ct. 3101, 3106 (1986) (quoting United States v. Martin Linen Supply Co., 430 U.S. 564, 572-73 (1977)); see also United Brotherhood of Carpenters \& Joiners v. United States, 330 U.S. 395, 408 (1947) ("For a judge may not direct a verdict of guilty no matter how conclusive the evidence.").

The rule that a criminal jury may return inconsistent verdicts, Dunn v. United States, 284 U.S. 390, 393 (1932), also may be explainable in terms of a desire to protect the jury's nullification function. See Bickel, Judge and Jury-Inconsistent Verdicts in the Federal Courts, 63 Harv. L. Rev. 649, 651 (1950) ("[T] he jury's function" is one of "finding a solution for those occasional hard cases in which "law and justice do not coincide.' ") (quoting J. Frank, Courts on Trial 127-28 (1949)).

231. In "cases having a de minimis cast or a note of contributory fault or of provocation ... [t]he jury will exercise its de facto powers to write these equities into the criminal law." H. Kalven \& H. Zeisel, The American Jury 285 (1966).

232. "Most often commended [is] the 18th century acquittal of Peter Zenger of seditious libel, on the plea of Alexander Hamilton ...." United States v. Dougherty, 473 F.2d 1113,1130 (D.C. Cir. 1972). See Pound, Law in Books and Law in Action, 44 Am. L. Rev. 12 (1910):

Jury lawlessness is the great corrective of law in its actual a dministration. The 
popular laws that do not reflect a community's basic values. ${ }^{233}$ The constitutional prohibition against directed verdicts of guilty ensures that in every case a jury has an opportunity to nullify the law. But if nullification were to gain undue prominence juries would usurp the role of legislatures to declare law, thus disrupting the democratic process. Further, criminal trials would become wide-ranging and protracted inquiries into both a defendant's background and the prosecutor's reasons for initiating charges. The courts' refusal to recognize a constitutional right on the part of a defendant to introduce evidence that might prompt nullification and to inform a jury of its nullification power ensures that nullification is confined to its proper role. These rules help ensure that when nullification occurs it is only because the prosecution offends fundamental and widely accepted values. ${ }^{234}$

Extending this limited constitutional protection to jury nullification does not preclude use of an outcome-oriented harmless error rule or prejudice test. Those commentators who assume that outcome-oriented harmless error rules cannot be squared with a jury's nullification power implicitly appeal to a misguided view of the nature of jury nullification. Under this view, a jury's nullification power permits it to render a verdict of acquittal for legally irrelevant reasons or for no reason at all. 235 It follows that a court intrudes upon a jury's prerogatives in concluding, for example, that unconstitutionally excluded evidence had no impact on the outcome. Even though admission of the evidence may

will of the state at large imposed on a reluctant community, the will of a majority imposed on a vigorous and determined minority, find the same obstacle in the local jury that formerly confronted kings and ministers.

Id. at 18.

233. Widespread distaste for the law explains the large number of acquittals in prosecutions brought under seditious libel, fugitive slave and alcohol prohibition laws. H. Kalven \& H. Zeisel, supra note 231, at 286. See Scheflin, supra note 226:

A juror who is forced by the judge's instructions to convict a defendant whose conduct he applauds, or at least feels is justifiable, will lose respect for the legal system which forces him to reach such a result against the dictates of his conscience. The concept of trial by a jury of one's peers is emasculated by denying to the juror his right to act on the basis of his personal morality. For if the jury is the "conscience of the community," how can it be denied the right to function accordingly?

Id. at 183 (citation omitted), cf. Williams v. Florida, 399 U.S. 78, 100 (1970) ("[T]he essential feature of a jury obviously lies in the interposition between the accused and his accuser of the commonsense judgment of a group of laymen, and in the community participation and shared responsibility that results from that group's determination of guilty or innocence.").

234. Dougherly, 473 F.2d at 1136-37; accord M. Kadish \& S. Kadish, Discretion to Disobey: A Study of Lawful Departures from Legal Rules 35, 59-66 (1973); cf. H. Kalven \& H. Zeisel, supra note 231, at 498 ("Perhaps one reason why the jury exercises its very real power so sparingly is because it is officially told it has none."). But see Christie, Lawful Departures from Legal Rules: "Jury Nullification" and Legitimated Disobedience, 62 Cal. L. Rev. 1289, 1297-1305 (1974) (arguing against the legitimacy of jury nullification). 
not affect the judgment of a reasonable jury, it could influence a jury to acquit for legally irrelevant reasons or for no reason at all.

Properly conceived, however, nullification does not refer to a power to acquit for any legally irrelevant reason or for no reason at all. lnsofar as it is constitutionally significant, jury nullification should contemplate a power to acquit for three categories of legally irrelevant reasons only: a defendant's motivations for committing the crime are so sympathetic that he does not deserve criminal punishment; a prosecutor has an impermissible motive for bringing charges such as a desire to silence a political opponent, harrass a defendant or further his own career; or the law under which a defendant is prosecuted conflicts with deep-seated contemporary values. Jury nullification, then, should not enable the jury to acquit "unreasonably." Instead, it should only permit the jury to acquit for reasons that, though legally irrelevant, reflect fundamental community values.

If jury nullification is confined to its proper place in the criminal justice scheme, it becomes evident that outcome-oriented harmless error rules need not be rejected outright. Instead, they can be revised to accommodate the limited constitutional protection that should be accorded jury nullification. The only constitutional right that ought to be derived from the jury's nullification powers is the right against having the court direct a verdict of gnilty, because this right ensures that a jury has an opportunity to nullify the law for constitutionally legitimate reasons. Harmless error rules must ensure that constitutional error does not restrict this opportunity in ways that are inconsistent with the reasons for extending this limited constitutional protection to the jury's nullification powers. It follows that constitutional error that is otherwise harmless does not justify reversal due solely to the jury's nullification powers unless the error incidentally bears a logical relationship to one of the three traditional bases of nullification.

The concern for jury nullification will not often require a court to vacate a conviction that it would otherwise uphold. Consider, for example, a case in which the trial court committed constitutional error by precluding defense counsel from cross-examining a government witness about his animosity for the defendant. If this witness' testimony was cumulative as a matter of law, the suggested reformulation of the Chapman rule would necessitate that the conviction be upheld. Jury nullification would require reversal only if the unconstitutionally excluded impeachment evidence also happened to be incidentally relevant to any of the three reasons for extending constitutional protection to jury nullification. This would occur in the rare case in which the excluded testimony not only constituted relevant impeachment evidence but also, for instance, suggested a political motivation for the prosecution. In such a case, constitutional error would have impaired the opportunity for nullification protected by the prohibition against directed verdicts of guilty. 


\section{CoNCLUSION}

The utility of the approach to harmless constitutional error proposed here is both practical and theoretical. On a practical level, the approach better guides lower courts, which have been forced to grapple with a misconceived body of law. The approach furnishes a principled means for courts to choose between the Chapman harmless error rule and a rule of automatic reversal, and between types of prejudice tests for defining rights at trial. It also clarifies the scope of review that the Chapman rule and an outcome-oriented prejudice test entail, reconciling these rules with a criminal jury's sixth amendment prerogative to decide the weight and credibility of the evidence.

This Article's proposed approach to harmless error, which begins by focusing on the purpose of the particular right violated, would also lead to a richer and more complete vision of the ultimate purposes of constitutional criminal procedure. Nowhere is the Supreme Court's increasing obsession with the truth-determination function of the criminal process more evident than in its opinions regarding harmless constitutional error. The approach to harmless error proposed here confronts the Court with the question of whether it is serious about protecting those rights that do not enhance, and may hinder, the search for the truth. 